\title{
Comments About Tsunami Occurrences in the Northern Caribbean
}

\author{
Mario Octavio Cotilla Rodríguez and Diego Córdoba Barba \\ Departamento de Física de la Tierra, Astronomía y Astrofísica 1. \\ Facultad de Ciencias Físicas, Universidad Complutense de Madrid
}

Spain

\section{Introduction}

Tsunamis [the Japanese word for "harbor wave"] are gravitational sea waves produced by any large-scale, short-duration disturbances of the ocean floor, principally by shallow submarine earthquakes, but also by submarine earth movement, subsidence, or volcanic eruption. They are characterized by long periods [ $\sim 5-60$ minutes] and low observable amplitudes on the open sea, although they may pile up to heights of $30 \mathrm{~m}$ or more and can cause extensive damage on entering shallow water along an exposed coast, often thousand of kilometers from the source. In other words, tsunamis are water displacements produced by fault movement, whereas seismic waves are directly caused by the fault motion. Earthquakes are a clear manifestation of rock deformation.

The general features of tsunamis are well known and have been discussed extensively in the literature. In order to clearly present the exposition, we define some specific terms in table 1. A further characteristic of tsunamis is that the fault in a sedimentary layer structure can generate a larger tsunami than a fault in a rigid structure. The study of tsunami deposits has only recently begun. Therefore, it is a good opportunity to get a more complete register of such phenomena.

Tsunami waves as a long-period ocean wave have a very low speed in deep water, of about $\sim 0.2 \mathrm{~km} / \mathrm{s}$ and often slower near the coastline producing the refraction phenomena and the increment of wave height. In the ocean where the depth can be considered constant the velocity is estimated by the following expression $\left[\mathrm{v}=(\mathrm{gh})^{1 / 2}\right.$, where $\mathrm{v}=$ speed $[\mathrm{m} / \mathrm{s}], \mathrm{g}=9.8 \mathrm{~m} / \mathrm{s}^{2}$, and $\mathrm{h}=$ ocean depth $\left.[\mathrm{m}]\right]$. Tsunamis triggered by an earthquake occur when a slab of oceanic crust descends near vertically along a fault, or where the vibration of a quake sets an underwater landslide into motion. Once formed, the tsunami advances across the ocean at speeds of 500 to $>900 \mathrm{~km} / \mathrm{h}$. A tsunami can pass undetected in the open ocean because its height is generally around one meter, and the distance between wave crests $[\lambda]$ is $100-700 \mathrm{~km}$. In contrast, when a tsunami enters shallow water near the coast, it becomes a destructive wave that moves slowly with the water piling up to heights of $\sim 30 \mathrm{~m}$. Since the speed of a tsunami is greater in the deep sea, the direction of propagation of a tsunami traveling in an open sea of variable depth gradually veers toward the shallowest zone. This process is known as wave refraction, and it is an important parameter in tsunami modeling. 
I

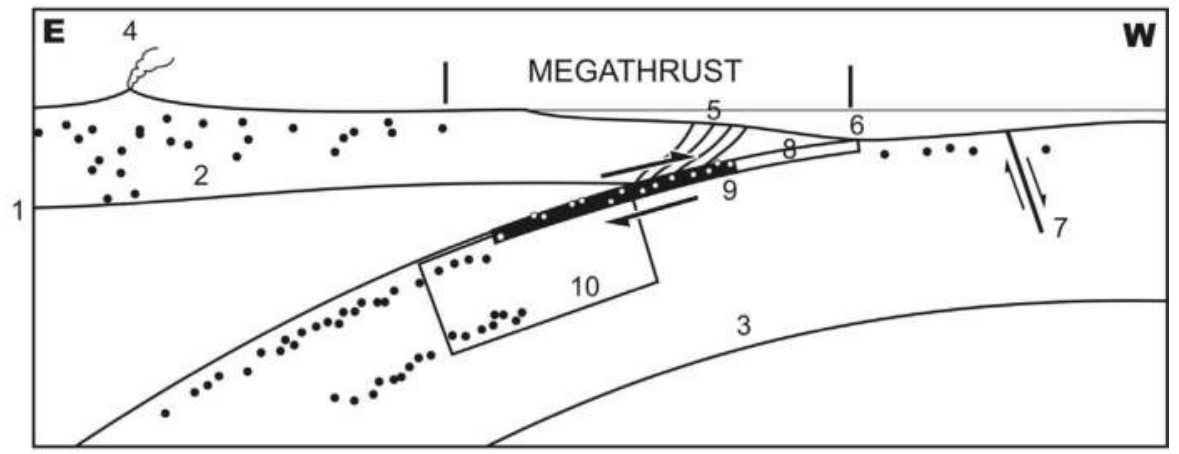

II

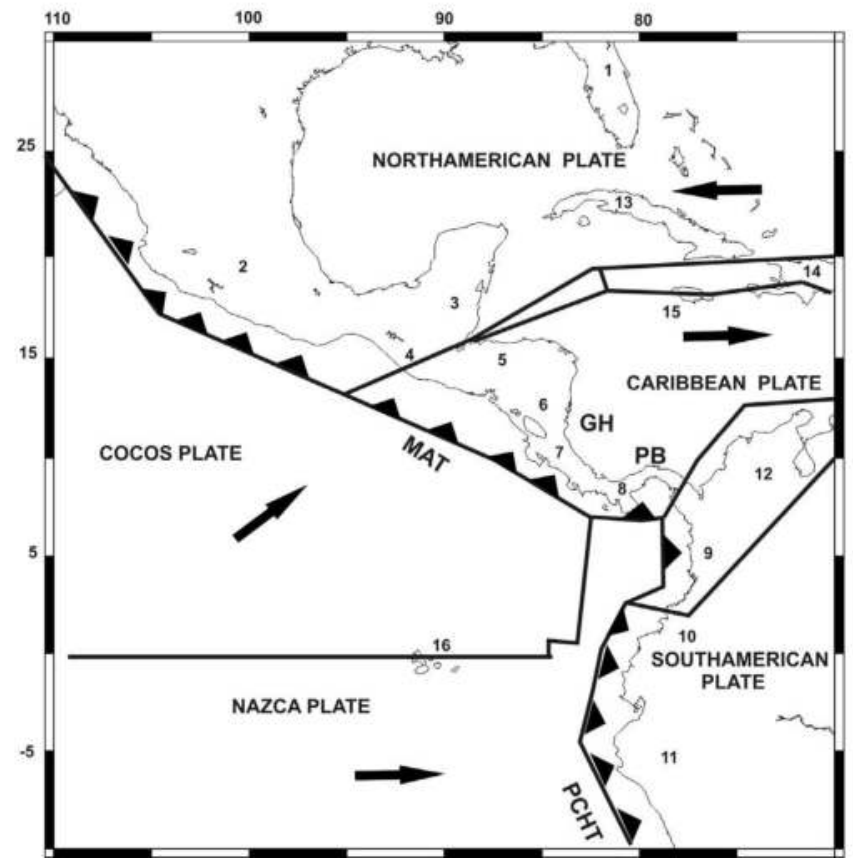

I $[1=$ Moho; (Black circles= focus of earthquakes); $2=$ Crustal earthquakes; $3=$ Subduction plane; $4=$ Volcanoes; $5=$ Accretionary wedge; $6=$ Trench; Earthquakes $(7=$ Outer rise; $8=$ Tsunami; $9=$ Thrust; $10=$ Slab).]

II [Localities (1= U.S.A.; $2=$ Mexico; $3=$ Guatemala; $4=$ El Salvador; $5=$ Honduras; $6=$ Nicaragua; $7=$ Costa Rica; $8=$ Panama; $9=$ Colombia; $10=$ Ecuador; $11=$ Peru; $12=$ Venezuela; $13=$ Cuba; $14=$ Hispaniola; $15=$ Jamaica; 16= Galapagos Islands); Structures (MAT= Mesoamerican trench; PCHT= Peru-Chile trench; $\mathrm{PB}=$ Panama block; $\mathrm{GH}=$ Gulf of Honduras); Heavy black arrows= sense of the plate movements.]

Fig. 1. I.- Model of megathrusts [modified from Satake and Tanioka], II- Tectonic contact zone between Caribbean and the Pacific plates. 
The majority of tsunamis are caused by large earthquakes. While volcanic eruptions and landslides can also produce tsunamis, these occur less frequently than with earthquakes. Tsunamis can result from earthquakes in subduction zones (Figure 1 I), where sudden vertical movements or subsidence of the sea floor are generated by faulting. Subduction is a complicated physical process in which a tectonic plate descends beneath another one. This process produces a large and narrow mountainous belt in the relief with a great number of earthquakes and some volcanoes. Such regions can be studied using the concept of a Wadati-Benioff zone (Table 1). In this, the earthquake foci [up to tens of kilometers] appear as a sequence in the depth.

The models of sea-floor spreading and plate tectonics show that the more important seismic zones on the arc islands are directly related with major underthrusts, along which the lithosphere plates converge and descend. Examples of this are the Aleutian arc [Gulf of Alaska] and the Chile-Peru arc [western margin of South America]. These segments are tectonically active and coincide with the two largest lithosphere plates [Pacific and America]. These two regions share some similarities, such as: 1) deep oceanic trenches; 2) a belt of active seismicity [Wadati-Benioff zones]; and 3) active volcanoes inside of subparallel, discontinuous mountain chains. Nevertheless, they differ in the type of contact. The Chile-Peru region is an ocean-continent transition along its entire length, with maximum foci at $\sim 650 \mathrm{~km}$ and large packages of Mesozoic and older crystalline rocks with clear, undeformed Tertiary sediments layers. In contrast, the Aleutian arc marks a transition between ocean and continent in its eastern part, where the true arc of islands is located. It has a maximum depth of occurrence for earthquakes of $170 \mathrm{~km}$ and a thick package of Mesozoic-Cenozoic deformed sediments. Two important earthquakes occurred in these regions, in 1960 in Chile and 1964 in Alaska, each of which generated a tsunami, of the thrust-fault type.

\begin{tabular}{|l|l|}
\hline \multicolumn{1}{|c|}{ Term } & \multicolumn{1}{c|}{ Description } \\
\hline Arrival time & Time of the first maximum of the tsunami waves. \\
\hline Backarc & $\begin{array}{l}\text { It is the region landward of a volcanic chain on the other side from a } \\
\text { subduction zone. }\end{array}$ \\
\hline $\begin{array}{l}\text { Benioff zone } \\
\text { Wadati-Benioff) }\end{array}$ & $\begin{array}{l}\text { A dipping planar zone of earthquakes that is produced by the } \\
\text { interaction of a downgoing oceanic plate with a continental plate. } \\
\text { These earthquakes can be produced by slip along the subduction } \\
\text { thrust fault or by slip on faults within the downgoing plate as a result } \\
\text { of bending and extension as the plate is pulled into the mantle. }\end{array}$ \\
\hline Breakwater & $\begin{array}{l}\text { Artificial structure such as a wall or water gate to protect a beach or } \\
\text { harbor from the force of waves. }\end{array}$ \\
\hline Forearc & $\begin{array}{l}\text { The region between the subduction zone and the volcanic chain } \\
\text { (volcanic arc). }\end{array}$ \\
\hline Forecast point & $\begin{array}{l}\text { The site or location where the authorities estimate the arrival of } \\
\text { tsunami. }\end{array}$ \\
\hline Interplate coupling & $\begin{array}{l}\text { It is the ability of a fault between two plates to lock and accumulate } \\
\text { stress. Strong interplate coupling means that the fault is locked and } \\
\text { capable of accumulating stress whereas weak coupling means that the } \\
\text { fault is unlocked or only capable of accumulating low stress. }\end{array}$ \\
\hline
\end{tabular}




\begin{tabular}{|c|c|}
\hline Landslide tsunami & $\begin{array}{l}\text { It can be produced by landslides of different origin (earthquake, } \\
\text { volcano, etc.). The effects are local and limited in area. }\end{array}$ \\
\hline Mareograph & Instrument to record the sea level gauge. \\
\hline Oceanic trench & $\begin{array}{l}\text { It is a linear depression of the sea floor caused by the subduction of } \\
\text { one plate under another. }\end{array}$ \\
\hline Paleotsunami & A tsunami that occurred prior to the historical record. \\
\hline Recession & The drawdown of the sea level prior to tsunami flooding. \\
\hline Run-up & $\begin{array}{l}\text { Value of the difference between the elevation of maximum tsunami } \\
\text { penetration on the coast and the sea level at the time of the tsunami } \\
\text { occurrence. It is only measured where there is a clear evidence of the } \\
\text { inundation limit on the shore. }\end{array}$ \\
\hline Sea level & The height of the sea at a given time measured. \\
\hline Seiche & $\begin{array}{l}\text { A sea movement initiated by a standing wave oscillating in a } \\
\text { partially or fully enclosed body of water. It can be start by long } \\
\text { period seismic waves, wind and water waves as a tsunami. }\end{array}$ \\
\hline Slab & $\begin{array}{l}\text { It is the oceanic crustal plate that underthrusts the continental plate } \\
\text { in a subduction and is consumed by the earth's mantle. }\end{array}$ \\
\hline Subduction & $\begin{array}{l}\text { A process of the oceanic lithosphere colliding with and descending } \\
\text { beneath the continental lithosphere. }\end{array}$ \\
\hline Subduction zone & $\begin{array}{l}\text { The place where two lithospheric plates come together, one riding } \\
\text { over the other. Most volcanoes on land occur parallel to and inland } \\
\text { from the boundary between the two plates. }\end{array}$ \\
\hline Tidal wave & $\begin{array}{l}\text { The wave motion of the tides. An erroneous synonymous of tsunami } \\
\text { and storm surge. }\end{array}$ \\
\hline Tide & $\begin{array}{l}\text { The alternate rise and fall of the ocean surface, or bodies of water } \\
\text { connected with the ocean. }\end{array}$ \\
\hline Tide station & The place where is obtained the tide data. \\
\hline Travel time & $\begin{array}{l}\text { Time that the first tsunami wave required to propagate from its } \\
\text { source to a given point on a coastline. }\end{array}$ \\
\hline Tsunameter & The instrument to detect in real-time tsunamis. \\
\hline Tsunamigenic & $\begin{array}{l}\text { It is referring to those earthquakes, commonly along major } \\
\text { subduction zone plate boundaries such as those bordering the Pacific } \\
\text { Ocean that can generate tsunamis. }\end{array}$ \\
\hline Tsunami zoning & $\begin{array}{l}\text { The designation of distinctive zones along the coastal areas with } \\
\text { varying degrees of tsunami risk and vulnerability, planning, } \\
\text { construction codes or evacuation of populations. }\end{array}$ \\
\hline Wave height & $\begin{array}{l}\text { Symbol H. The vertical distance between the trough and the crest of } \\
\text { the sea wave while the tsunami is traveling toward the land. }\end{array}$ \\
\hline
\end{tabular}

Table 1. Some terms used to measure and describe tsunamis. 
On the other hand, fault motions such as a strike-slip displacement are not capable to generate a tsunami because they are horizontal and do not change the sea floor. Different authors have stated that on gently sloping coasts, such as in the California area, large tsunamis are quite rare, and the relatively small tsunamis are probably generated by faulting at the bottom of the ocean. Table 2 contains the main fault types. As we mentioned before, most tsunamis are caused by large shallow earthquakes that occur on major plate boundaries. Thus, many tsunami sources are located in the Circum-Pacific Ocean zone [the Aleutian Islands, Central America, Japan, Kuril Islands, and Tonga]. Nevertheless, no large tsunamis are generated where the plate motion is a transform-fault type, as found in the west coast of North America, where the large earthquakes are strike-slips that occur on land. Historical geological data show that landslides sometimes generate tsunamis and increase tsunami magnitude. Nevertheless, the occurrence of tsunamis induced by landslides is minimal. A good example of that phenomena occurred in the locality of Loma Prieta [California, U.S.A.]. It was affected in 1989 by a small earthquake. Although the epicenter was located on land, this seismic event produced underwater local slums [landslides] that generated a small tsunami in Monterey Bay. Another example of this is the 1998 tsunami of Papua, New Guinea.

\begin{tabular}{|l|l|}
\hline \multicolumn{1}{|c|}{ Fault type } & \multicolumn{1}{c|}{ Description } \\
\hline Normal & $\begin{array}{l}\text { They are developed in crust undergoing extension in which the } \\
\text { maximum principal compressive stress is vertical. Also, a dip-slip fault } \\
\text { on which the hanging wall has moved downward relative to footwall. }\end{array}$ \\
\hline Reverse & $\begin{array}{l}\text { A fault on which the hanging wall appears to have moved upward } \\
\text { relative to the footwall. The dip of a reverse fault is relatively steep, } \\
\text { greater than } 45^{\circ} .\end{array}$ \\
\hline Thrust & $\begin{array}{l}\text { A fault with a dip of } 45^{\circ} \text { or less over much of its extent on which the } \\
\text { hanging wall appears to have moved upward relative to the footwall. }\end{array}$ \\
\hline Strike-slip & $\begin{array}{l}\text { They are faults that have slip vectors parallel (horizontal) to their strike. It } \\
\text { is frequent to find some comments using the term lateral as a synonym for } \\
\text { strike-slip. The fault surface is usually near vertical and the footwall } \\
\text { moves either left or right or laterally with very little vertical motion. A } \\
\text { strike-slip fault with left-lateral motion is known as sinistral fault. And the } \\
\text { other type (right-lateral motion) is also known as dextral fault. }\end{array}$ \\
\hline
\end{tabular}

Table 2. Main fault types.

Tsunami earthquakes are those tsunamis with greater amplitudes than would be expected from their seismic waves. They have low magnitudes that can be not felt by the population, who may thus not take precautionary evasive measures. Some results have shown that sources in tsunami earthquakes cannot be explained by a regional signal identifiable for other moderate to major events along the same subduction system. Also, it is difficult create fault models that fit the distribution of tsunami heights.

Magnitude scales allow tsunami sizes to be determined. Some scales are available for this, such as the Imamura-Ida scale in five levels. Also, intensity scales [Sieberg-Ambraseys] exist, such as the one used for earthquakes. This scale is principally employed for old tsunamis for which no instrumental records exist $\left[\mathrm{m}=\log _{2} \mathrm{H}\right.$, where $\mathrm{m}$ is the magnitude and $\mathrm{H}$ is tsunami height [run-up height]]. Another scale is the Abe magnitude scale, developed 
for trans-Pacific tsunamis, of $\mathrm{M}_{\mathrm{T}}=\log \mathrm{H}+\mathrm{C}+9.1$. A range of 100 to $3,500 \mathrm{~km}$ is included the expression: $\mathrm{M}_{\mathrm{T}}=\log \mathrm{H}+\log \Delta+5.8$. In both formulas, $\mathrm{H}$ is the maximum amplitude [meters] on tide gauges. This scale allows the seismic moment of the tsunamigenic earthquake to be measured as the overall size of a tsunami at the source. Table 3 shows classifications of tsunami sizes. Table 4 shows a classification of three levels of tsunamis, taking into account the distance from the source. Three types of tsunamis and tsunami earthquakes were proposed to occur in subduction zones, by examining the source and the tsunami earthquakes at the source locations: 1) typical interplate earthquakes; 2) intraplate earthquakes; and 3) tsunami earthquakes (Table 5). Tsunamis from typical interplate earthquakes can be used to demonstrate that the slip is concentrated in asperities. Intraplate earthquakes at the outer rise in the subducted slab and in the overlying crust can all be tsunamigenic [i.e., 1995 in the Kuril Islands]. It was suggested that there are two types of tsunami earthquakes: 1) very anomalous; and 2) moderate (Table 6). We can mention four cases of this: 1) 1896 Sanriku Islands; 2) 1946 Aleutian Islands; 3) 1992 Nicaragua; and 4) 1996 Peru. All of these had sources between the trenches and were at depths of $10 \mathrm{~km}$ beneath the accretionary wedge. This source is a shallow extension of the seismogenic zone for typical interplate earthquakes.

\begin{tabular}{|c|c|c|}
\hline $\mathbf{N}^{\mathbf{o}}$ & Classification & Mw / Rupture length $\mathbf{( k m )}$ \\
\hline 1 & Giant tsunami & $\mathrm{Mw} \geq 9,1 />550$ \\
\hline 2 & Major tsunami & $8,4<\mathrm{Mw}<9 /<550$ \\
\hline 3 & Local tsunami & $\mathrm{Mw}<8,4 /<240$ \\
\hline
\end{tabular}

Table 3. Classification of tsunamis according to Mw and size of source areas (Furumoto).

Schematic cross-sections of faults for a subduction zone earthquake and the vertical deformation of the ocean floor show a vertical deformation pattern along the cross-section of the subduction earthquake. If the fault is $100 \mathrm{~km}$ wide, the vertical uplift extends toward land, and the tsunami arrives early. In contrast, if the fault is narrower, $40 \mathrm{~km}$, the vertical deformation is limited to a smaller area, and the tsunami arrives at the coast later. Also, there are two models of the relationship between normal fault earthquakes and tsunami earthquakes. These were generated despite the relatively small magnitude of two of the largest and most widespread tsunamis in history. The 1929.03.27 Aleutian Islands earthquake $[\mathrm{M}=8.1, \mathrm{~h}=50 \mathrm{~km}]$ was located beneath the Aleutian trench. It is interesting and striking that, in the Aleutian and Sanriku regions, large normal-fault earthquakes occur along the trench axis. The 1933 Sanriku earthquake is the largest of such a type of event. Normal-fault earthquakes may imply the presence of a weak zone along the inner margin of the trench. It is in this part of the trench that the tsunami earthquake of 1896 occurred. The situation is slightly different along the Aleutian zone. The two tsunami earthquakes, the 1896 Sanriku and the 1946 Aleutian Islands earthquakes, are very similar to each other.

\begin{tabular}{|c|c|c|}
\hline $\mathbf{N}^{\mathbf{0}}$ & Classification & Distance from the source (km) \\
\hline 1 & Local & $<100$ \\
\hline 2 & Regional & $>700-750$ \\
\hline 3 & Distant - Teletsunami & $>750$ \\
\hline
\end{tabular}

Table 4. Classification of tsunamis according to the distance from the source. 


\begin{tabular}{|c|l|}
\hline Type & \multicolumn{1}{c|}{ Description } \\
\hline $\begin{array}{c}\text { Typical interplate } \\
\text { earthquake }\end{array}$ & $\begin{array}{l}\text { Occur at the seismogenic interface or megathrust between } \\
\text { subducting and overlying plates. }\end{array}$ \\
\hline $\begin{array}{c}\text { Intraplate } \\
\text { earthquake }\end{array}$ & $\begin{array}{l}\text { There are two types: A) Outer-rise event when its location is outside } \\
\text { the trench; B) Slab-earthquake when it occurs within the subducting } \\
\text { slab. The slab earthquakes include deep earthquakes. In the } \\
\text { overlying crust are also intraplate earthquakes. }\end{array}$ \\
\hline Tsunami earthquake & $\begin{array}{l}\text { Locate at a shallow extension of the interpolate seismogenic zone, } \\
\text { beneath the accretionary wedge. }\end{array}$ \\
\hline
\end{tabular}

Table 5. Types of tsunami and tsunamigenic earthquakes in subduction zones.

\begin{tabular}{|c|l|}
\hline Type & \multicolumn{1}{c|}{ Description } \\
\hline Very anomalous & $\begin{array}{l}\text { It occurs at an accreting margin with large amounts of sediments and } \\
\text { the accretionary prism where occasional slumping causes the tsunami } \\
\text { earthquake. }\end{array}$ \\
\hline Moderate & $\begin{array}{l}\text { It occurs in a subduction zone with little sediment where rupture in } \\
\text { subducted sediment is responsible for large tsunamis. }\end{array}$ \\
\hline
\end{tabular}

Table 6. Types of tsunamis earthquakes (Kanamori and Kikuchi).

There is currently a lot of scientific data about tsunamis in the field, generated mainly since the 1950s. These contributions increased dramatically in quantity after the Nicaragua tsunami of 1992. We list some of the most relevant papers and books used here to guide readers who are interested in the topic. Each section lists this crucial reference information. This chapter will include a first section listing the most significant aspects of the research on tsunamis. The second section contains the most relevant information on reported and registered tsunamis in the Pacific Ocean. This is the region with the largest number of tsunamis, and examining these will allow the comparison with the following two sections, on the Atlantic Ocean and the Caribbean region. In particular, our goal is to analyze the northern Caribbean. The last section includes the techniques and resources used for tsunami detection, as well as data and recommendations that can serve the people who live in the coastal zones.

\section{Tsunamis studies and historic tsunamis}

The sources for this section include: Bryant, 2001; Cotilla and Córdoba, 2010; Dmowska and Saltzman, 1998; Iida and Iwasaki, 1981; NOAA, 2004; Polet and Kanamori, 2000; Satake, 2005; Sauber and Dmowska, 1999; Shuto, 1993; Sieberg, 1932; Titov, 2009; and UNESCOIOC, 1998.

The data about most historic tsunamis can be found in old literature. That information can contain descriptions about casualties, damages, and observed run-up heights. The authors prepared in 2010 a world tsunami catalog. They listed the most significant tsunamis [479 B.C. - 2011]. Among them is the Aleutian Islands event [1946], where the magnitude of the earthquake was relatively small but produced one of the largest and most widespread tsunamis in history. This historical relationship of tsunamis [522 events] was prepared in order to show in a simple way the time and geographical distributions of such natural 
phenomena. The catalog includes the 18 great tsunamigenic earthquakes [M $\geq 8.6], 12$ of which occurred in the $20^{\text {th }}$ century. It has two columns containing the date and the geographical localization of tsunamis. An additional column includes the main characteristics of the event. The two further columns give the code of tsunamigenic region proposal by other authors [for the Pacific Ocean], or by us [this is the most complete as it includes all regions]. We have found in our research that some catalogs merely repeat other results, incorporating very little new information. Nevertheless, it is possible to identify clear repetitions of mistakes. We also prepared a set of tables which clearly present the time distribution, the quantities, and the distribution by region of the largest tsunamis that have occurred (Tables 7, 8, 9 and 10). The majority of the largest tsunamis were located in the Pacific Ocean [17 of 18]. Specifically, table 9 shows the largest tsunamigenic potential of the Pacific region.

\begin{tabular}{|c|c|c|c|}
\hline Time period & Total & Time period & Total \\
\hline $684-1600$ & 1 & $1901-2000$ & 10 \\
\hline $1601-1900$ & 5 & $2001-2011$ & 2 \\
\hline
\end{tabular}

Table 7. Great tsunamigenic earthquake by time period.

\begin{tabular}{|c|c|c|c|c|}
\hline $\mathbf{N}^{\mathbf{0}}$ & Site & Date & By region & By large regions \\
\hline 1 & U.S.A. (Alaska) & 1964.03 .28 & 1 & \multirow[t]{7}{*}{7} \\
\hline 2 & \multirow[t]{3}{*}{ Aleutian Islands } & 1946.04 .01 & \multirow[t]{3}{*}{3} & \\
\hline 3 & & 1957.03.09 & & \\
\hline 4 & & 1965.02 .04 & & \\
\hline 5 & Kuril Islands & 1918.09 .08 & 1 & \\
\hline 6 & \multirow[t]{2}{*}{ Russia (Kamchatka) } & 1841.05 .17 & \multirow[t]{2}{*}{2} & \\
\hline 7 & & 1952.11 .04 & & \\
\hline 8 & Chile (Valdivia) & 1837.11 .07 & \multirow[t]{5}{*}{5} & \multirow[t]{6}{*}{6} \\
\hline 9 & Chile (Arica) & 1868.08 .13 & & \\
\hline 10 & Chile (Iquique) & 1877.05 .10 & & \\
\hline 11 & Chile (Atakama) & 1922.11 .10 & & \\
\hline 12 & Chile-Perú & 1960.05 .22 & & \\
\hline 13 & Ecuador-Colombia & 1906.01 .31 & 1 & \\
\hline 14 & Japan & 684.11 .29 & \multirow[t]{4}{*}{4} & \multirow[t]{4}{*}{4} \\
\hline 15 & Japan (Sanriku) & 1896.06 .15 & & \\
\hline 16 & Japan (Tsugaru Peninsula) & 1983.05 .26 & & \\
\hline 17 & Japan (Sendai) & 2011.03 .11 & & \\
\hline 18 & Indean Ocean & 2004.12 .26 & 1 & 1 \\
\hline
\end{tabular}

Table 8. Relation of great tsunamigenic earthquakes. 


\begin{tabular}{|l|c|c|c|c|}
\cline { 2 - 5 } \multicolumn{1}{c|}{} & Tsunamis & $\begin{array}{c}\text { Great } \\
\text { tsunamis }\end{array}$ & $\begin{array}{c}\text { Maximum } \mathbf{M}_{\mathbf{T}} / \\
\text { Deaths }\end{array}$ & Run-up (m) \\
\hline Maximum & 522 & 18 & $9,4 />1$ million & $>100$ \\
\hline Pacific Ocean & 393 & 17 & $9,4 />1$ million & $>100$ \\
\hline $\begin{array}{l}\text { Central America } \\
\text { [eastern / western] }\end{array}$ & {$[14 / 47]=61$} & {$[0 / 1]$} & {$[? / 8,7] /[-/ 5]$} & {$[-/>50]$} \\
\hline Lesser Antilles & 19 & - & $-/ 40$ & 20 \\
\hline Northern Caribbean & 61 & - & $-/ \sim 9.000$ & 18 \\
\hline Southern Caribbean & 27 & - & $8,1 / 18$ & 10 \\
\hline
\end{tabular}

Table 9. Brief comparison between tsunamis' characteristics to four regions.

\begin{tabular}{|l|c|l|c|l|c|}
\hline \multicolumn{1}{|c|}{ Region } & Year & \multicolumn{1}{c|}{ Region } & Year & \multicolumn{1}{c|}{ Region } & Year \\
\hline Mediterranean Sea & 479 B.C. & Jamaica & 1688 & Alaska & 1788 \\
\hline Indonesia & 416 & Virgin Islands & 1690 & Marianas Islands & 1819 \\
\hline Japan & 684 & Mexico & 1732 & Aleutian Islands & 1827 \\
\hline Venezuela & 1530 & Kuril Islands & 1737 & El Salvador & 1859 \\
\hline Honduras & 1539 & Russia (Kamchatka) & 1737 & Guatemala-El Salvado & 1859 \\
\hline Chile & 1562 & Hispaniola & 1751 & Hawaiian Islands & 1868 \\
\hline Panama & 1621 & Lesser Antilles & 1751 & New Hebrides Islands & 1875 \\
\hline Peru & 1664 & Haiti & 1769 & Puerto Rico & 1918 \\
\cline { 1 - 4 } Philippine Islands & 1677 & \multicolumn{3}{|l}{} \\
\cline { 1 - 5 }
\end{tabular}

Table 10. First reports of tsunamis by region.

Several shallow subduction zone earthquakes have caused destructive tsunamis. These phenomena are produced by large shallow earthquakes beneath the ocean floor. It is known that a great shallow earthquake beneath the ocean floor should be expected to be followed by a tsunami caused by the large displacement of water near the ocean floor. Subduction of the oceanic lithosphere occurs along massive interplate thrust faults that are the contact surfaces between overriding and underthrusting plates in convergent margins. The megathrusts accommodate the convergent motions by varying portions of seismic and aseismic slips, with significant variations on geometry and maximum earthquake size from region to region. About $90 \%$ of the seismic moment released by global earthquakes occurs near subduction zones, with most events, including the largest recorded events, involving slip on a megathrust. Interplate thrust faults in subduction zones host the largest earthquakes and a majority of the seismic energy released in the world. The seismicallycoupled portion of the megathrusts extends $\sim 100 \mathrm{~km}$ across the depth range of 5-60 km, with the convergent motions between underthrusting and overriding plates accommodated by a mixture of these processes: 1) earthquake slip; 2) postseismic deformation; and 3) interseismic creep. This models the great earthquake sequences.

Studies of the largest earthquakes along megathrusts in different subduction zones have suggested some correlations between convergence rate, lithospheric age, sediment supply, bathymetric features, and back arc spreading (Table 1). It contains a model of a typical earthquake in a subduction zone. This type of earthquake occurs at the seismogenic 
boundary between the subducting and overlying plates. On the other hand, intraplate earthquakes include out-rise events, slab events, and crustal earthquakes. The source region of tsunami earthquakes is beneath the most trenchward part of the accretionary wedge. Figure 1 shows a comparison between a typical interplate earthquake and a tsunami earthquake. It is easy to observe the slip at varying depths on the megathrust and the resulting surface vertical displacement. Large slips at very shallow depths in low rigidity sediments cause large ocean bottom displacements relative to comparable seismic moment events with a lesser slip in higher rigidity material at greater depths along the megathrust. Some outer-rise events have caused significant tsunami damage, such as the mentioned before 1933 Sanriku earthquake [Mw=8.4, 3,000 casualties] and the 1977 Sumba earthquake $[\mathrm{Mw}=8.3,150$ casualties]. Further examples are the 1896.06.15 Sanriku earthquake, and the 1946.04.01 Aleutian Islands earthquake [M=7.4]. Earthquakes occurring in the crust of the overlying plate can also be tsunamigenic, as seen for the 1992 Flores Indonesia earthquake [Mw=7.8] and the 1993 Southwest Hokkaido Japan earthquake [Mw=7.6]. Earthquakes in the subducting plate are commonly called slab event [i.e., the 1993 Guam earthquake, $\mathrm{Mw}=7.7$, and the 1994 Kuril earthquake, $\mathrm{Mw}=8.2]$. The last one mentioned was one of the strongest earthquakes that occurred in and around Japan.

Tsunami generation is one of the most important subduction processes. Most shallow large earthquakes in subduction zones caused tsunamis. An earthquake is tsunamigenic if it generates a tsunami, and it is a tsunami earthquake if it generates a much large tsunami than expected from its seismic waves. Most, but not all, large or great tsunamigenic earthquakes are typical interplate earthquakes. In these events, the fault plane is located along the interface of the subducting and overlying plates. At most subduction zones, the seismogenic interface extends from a depth of about $10-40 \mathrm{~km}$. The source extent of large interplate earthquakes is limited to the seismogenic zone. As a result of underthrusting, the seismogenic zone is uplifted while the surface above the deeper end subsides. The coseismic deformation is generally in the direction opposite to the interseismic deformation, with the gradual crustal deformation in earthquake cycles. Also, some tsunamis in subduction zones result from shallow intraplate earthquakes.

\section{Tsunamis in the Pacific region}

We assumed in our world catalog the division in 24 tsunamigenic regions proposed by other authors for the Pacific Ocean. The majority of tsunamis have been generally local to a particular area. It seems like the tsunamis such as in Alaska [1964.03.29] and Chile [1960.05.22] are not characteristic of this region. The Alaskan-Aleutian zone is a typical subduction zone where great tsunamigenic interplate earthquakes repeat. Also, the Pacific coast of Central America-Mexico region has been the setting of several great earthquakes (Table 11). Many of these produced tsunamis in the same period.

The Alaska-Aleutian region is a typical subduction zone where great tsunamigenic interplate earthquakes repeat in time. In this zone, the North American plate [from the north] is subducted by the Pacific plate in the Aleutian trench. This zone is a large island arc from southern Alaska to the western Aleutian. Some strong earthquakes have occurred in it, such as those in 1938 [Mw=8.2], $1946[\mathrm{Mw}=8.3], 1957$ [Mw=8.6], 1964 [Mw=9.2], 1965 [Mw=8.7], 1986 [Ms=8.0], and 1996 [Ms=7.9]. Thus, the Cascadia Subduction zone is a type of convergent plate boundary which stretches from northern Vancouver Island to northern 
California [with two triple junctions at its north and south ends]. It is a very long, sloping fault that separates the Juan de Fuca, Explorer, and Gorda plates from the North American plate. The ocean floor moves towards and beneath the North American plate at approximately $4 \mathrm{~cm}$ /year. The Cascadia Subduction zone is where the two plates meet, and some large, offshore earthquakes have occurred here, producing devastating tsunamis.

\begin{tabular}{|l|l|l|l|}
\hline \multicolumn{1}{|c|}{ Zone / Region } & Year / Mw & \multicolumn{1}{c|}{ Zone / Region } & Year / Mw \\
\hline Chile / Pacific & 1960 / 9,5 & Assam / Mediterranean & 1950 / 8,6 \\
\hline Alaska / Pacific & 1964 / 9,2 & Aleutian / Pacific & 1957 / 8,6 \\
\hline Kamchatka / Pacific & 1952 / 9,0 & Kurile Islands / Pacific & 1963 / 8,5 \\
\hline Ecuador / Pacific & $1906 / 8,8$ & Chile / Pacific & 1922 / 8,5 \\
\hline Aleutian / Pacific & 1965 / 8,7 & Banda Sea / Indic & 1938 / 8,5 \\
\hline
\end{tabular}

Table 11. The largest earthquakes to the $20^{\text {th }}$ century.

The tectonic setting of Central America is given by the interaction of the Cocos, Caribbean, and Nazca plates (Figure 1 II). The Cocos plate subducts under the Caribbean plate along the Middle American trench. From Mexico to Central America, the subduction process is normal, and the Wadati-Benioff zone is well-defined by intermediate and deep earthquakes. But in southern Costa Rica, subduction becomes its shallowest due to the presence of Cocos Ridge. This structure collides with the Cocos plate, generating a buoyant effect. That process makes it difficult for the Cocos plate to penetrate under the Caribbean plate. This effect is responsible for the lack of deep seismicity there as well as for inhibiting volcanism and the uplift of the Talamanca Range, Costa Rica. The limit between the Cocos and Nazca plates is the Panama Fracture Zone. It is composed of north-south trending faults located in front of the Pacific coast of Costa Rica and Panama. The boundary between the Caribbean plate and Nazca plate is quite ambiguous. The Panama Deformed Belt lies towards the Caribbean coast of Costa Rica and its convergent margin.

The Middle America margin off Costa Rica-Nicaragua converges with the Cocos plate at an equivalent rate; it also has sparse trench sediment but it varies in crustal structure and the subducting oceanic crust. The morphology of this convergent region is well known as the variation of arc volcanism. The main features of this Wadati-Benioff zone geometry are: 1) a smooth contortion of the seismically active slab under the Nicaragua-Costa Rica border; 2) a decrease in the maximum depth of earthquakes from $200 \mathrm{~km}$ under Nicaragua to less than $50 \mathrm{~km}$ under southern Costa Rica; 3) a segmentation of the slab under Central Costa Rica; and 4) the abrupt termination of the seismically active slab at $83^{\circ} \mathrm{W}$ coincident with the southeastern end of the Central America active volcanic chain. No evidence of a WadatiBenioff zone deeper than $50 \mathrm{~km}$ is found southeastern of Punta Vista. The subduction zone from Nicaragua to Costa Rica is divided into four segments: 1) Nicaragua; 2) Northern Costa Rica; 3) Central Costa Rica; and 4) Southern Costa Rica. Also, the differences in coupling between the Cocos and Caribbean plates for Nicaragua and Costa Rica can be correlated with the characteristics [bathymetric features] of the subducted ocean floor. It is important to note that, historically, large underthrust earthquakes [Ms>7.0] have occurred along the NW and SE segments but not within the Central segment.

The epicentral distribution of earthquakes shows a high level of seismic activity along the whole Middle American trench. The Panama Fracture Zone also has intense seismic activity. In the north [Mexico], the seismic activity suggests the shallowest mode of subduction; 
similarly, in the south, there is no seismicity below $50 \mathrm{~km}$. Most of earthquakes are shallow and related to the Cocos-Caribbean subduction zone. Some large earthquakes have occurred that are associated with the Middle American trench. These earthquakes are differentiated into two groups according to the depth of occurrence [0-30 and 40-200 km]. It is well known that the seismicity on the Caribbean coast of Central America is low. Within it, only three large earthquakes occurred during the last century, each of which generated small tsunamis. If the probability of tsunami occurrence is proportional to the rate of seismicity, the possibility of tsunamis occurring should be lower. Nevertheless, it was found that the area has been hit by numerous tsunamis, which have caused damage and loss of life. In table 12, we list the largest earthquakes and tsunamis of the Pacific coast of Central America. However, these tsunamis might not have been dangerous if the earthquake source was inland. Regional tsunamis from elsewhere in the Pacific region have also hit the coasts of Central America. These tsunamis flooded villages, washing out houses and producing great damage to property, and have produced $~ 350$ casualties. As we mentioned previously, the majority of the tsunamis of Central America have taken place at the Pacific coast. This is normal considering that the most active margin of the Caribbean plate is the Middle American trench that is located in front of the Pacific coast of Central America. Based on this data set, it seems that Cocos-Central America is the most important environment for generating tsunamigenic earthquakes on the Pacific coast of Central America. The largest tsunamis of this area were the Guatemala-El Salvador tsunamis [1902.02.26 and 1902.04.19] and the Nicaragua tsunami [1992.09.01], which produced 185 and 170 deaths, respectively.

\begin{tabular}{|c|c|c|c|l|c|}
\hline Date & Coordinates & $\mathbf{H}(\mathbf{k m})$ & $\mathbf{M s}$ & \multicolumn{1}{|c|}{ Tsunami locality } & Runup (m) \\
\hline 1844.05 & $11,20 \mathrm{~N} / 84,0 \mathrm{~W}$ & 30 & 7,4 & Nicaragua Lake & \\
\hline 1854.08 .05 & $08,50 \mathrm{~N} / 83,00 \mathrm{~W}$ & 33 & 7,3 & Dulce Gulf & \\
\hline 1884.11 .05 & $40,00 \mathrm{~N} / 76,00 \mathrm{~W}$ & 100 & 7,5 & Colombia (Acando) & \\
\hline 1902.04 .19 & $14,90 \mathrm{~N} / 91,50 \mathrm{~W}$ & 60 & 7,5 & Guatemala (Ocos) & 2,5 \\
\hline 1906.01 .31 & $01,00 \mathrm{~N} / 81,30 \mathrm{~W}$ & & 8,1 & Ecuador-Panama-Costa Rica & \\
\hline 1915.09 .07 & $13,90 \mathrm{~N} / 89,60 \mathrm{~W}$ & 60 & 7,7 & El Salvador (South coast) & 0,6 \\
\hline 1916.05 .25 & $12,00 \mathrm{~N} / 90,00 \mathrm{~W}$ & & 7,5 & El Salvador & 0,2 \\
\hline 1934.07 .18 & $08,10 \mathrm{~N} / 82,60 \mathrm{~W}$ & & 7,5 & Panama (Chiqui Gulf) & \\
\hline 1941.12 .05 & $08,70 \mathrm{~N} / 83,20 \mathrm{~W}$ & & 7,6 & Costa Rica (Dominsal) & \\
\hline 1950.10 .05 & $10,00 \mathrm{~N} / 85,70 \mathrm{~W}$ & 60 & 7,7 & Costa Rica-Nicaragua-El Salvador & \\
\hline 1950.10 .23 & $14,30 \mathrm{~N} / 91,80 \mathrm{~W}$ & & 7,3 & Guatemala-El Salvador (coast) & \\
\hline 1956.10 .24 & $11,50 \mathrm{~N} / 86,50 \mathrm{~W}$ & & 7,2 & Nicaragua (San Juan Sur) & \\
\hline 1957.03 .10 & $51,63 \mathrm{~N} / 171,4 \mathrm{~W}$ & & 8,1 & El Salvador (Acajutla) & \\
\hline 1960.05 .22 & $38,20 \mathrm{~N} / 73,50 \mathrm{~W}$ & 32 & 8,5 & Guatemala-El Salvador & \\
\hline
\end{tabular}

Table 12. The largest earthquakes [Ms $\geq 7,2]$ and tsunamis of the Pacific coast in Central America.

\section{Tsunamis in the Atlantic Ocean}

Many sources have been consulted in order to develop this section, including: Cotilla, 2007; Cotilla and Córdoba, 2010; Grindlay et al., 2005; Lander et al., 1992; McNamara et al., 2005; Polet and Kanamori, 2000; and Rubio, 1982. 
The vast majority of the area of the Atlantic Ocean is not tsunamigenic [for example, the Gulf of Mexico]. The region is clearly divided into different areas: Mediterranean, Caribbean, Azores, Portugal, and the eastern part of South and North America. Our interest focuses on the Caribbean area, and in particular on the northern Caribbean area. We will later discuss and include data on the tectonic, seismicity, and focal mechanisms, in order to understand the actual tectonic behaviour of the region. Note that, in 1962, a seismic sea waves catalog was prepared for the eastern Mediterranean $\left[31^{\circ}-44^{\circ} \mathrm{N} / 18^{\circ}-36^{\circ} \mathrm{E}\right]$, which included 141 events. Our world catalog contains the most significant tsunamis in the Atlantic area. The oldest data about tsunamis came from the Mediterranean area [479 B.C.]. The second most important tsunamigenic area of the Atlantic Ocean is very well-defined and corresponds to the Mediterranean Sea (Table 13). In it, there are several seismic sources that are active and important, such as: 1) the Azores Islands; 2) the eastern end of the PBZ Europe-Asia [SW of Portugal] associated with the earthquake and tsunami of November 1, 1755; 3) Assam [north of Africa]; and 4) Greece-Turkey. This region has a very high level of risk for many populations and tourist facilities. Nevertheless, there have not been any reports of great tsunamigenic earthquakes in the Atlantic Ocean. Table 10 contains the year of the first report of tsunamis in 25 regions. From this, it is easy to understand that the first reports are associated with human settlements.

\begin{tabular}{|l|c|l|c|c|c|}
\hline \multicolumn{1}{|c|}{ Region } & Total & \multicolumn{1}{c|}{ Region } & Total & Region & Total \\
\hline Caribbean Sea & 114 & Canary Islands & 1 & Azores Islands & 15 \\
\cline { 1 - 4 } Mediterranean Sea & 24 & England & 1 & \multicolumn{2}{|c}{} \\
\cline { 1 - 3 }
\end{tabular}

Table 13. Tsunamis in the Atlantic Ocean.

The main differences between the tsunamigenic sources of both the Pacific and the Atlantic Oceans are given in Table 9. Among other things, the first zone is far more active, dangerous, and complex than the other. Nevertheless, the event of November 1, 1755, was without a doubt one of the most important in all history, and while it occurred just southwest of Portugal, it reached areas as far away as the Caribbean about 7-8 hours later.

\section{Tectonic of the Caribbean region}

The following sources were used here: Cotilla, 2007; Cotilla and Córdoba, 2011, 2010, 2009, 2007; and Cotilla et al., 2007.

The Caribbean domain and Central America form a small lithospheric plate inserted between the North American and South American plates that is moving eastward relative to the North American plate (Figure 2 II). The North American and Caribbean Plate Boundary Zone [PBZ] is an irregular seismogenic area, $100-250 \mathrm{~km}$ wide, with left-lateral strike-slip deformation extending over 2,000 km along the northern border of the Caribbean Sea. The main structural element in the PBZ is the Cayman trough, a submarine pull-apart basin of $1,100 \mathrm{~km}$ of oceanic crust at the Mid-Cayman spreading centre, a $100 \mathrm{~km}$ long-jog between left-lateral faults of the plate boundary. This spreading centre has been active since the Middle Eocene and has a rate of $1.5 \mathrm{~cm} / \mathrm{yr}$. Further to the east of it are the islands of Jamaica, Hispaniola, and Puerto Rico.

The Cayman strike-slip system is divided into two branches: 1) the northern branch from the Cayman spreading centre to the Puerto Rico trench; and 2) the southern branch from Central America to Haiti (Figures 2 II). The western part of the southern branch, the Walton- 
Plantain Garden-Enriquillo fault, is clearly active and runs from Jamaica up to the Muertos trough. Within the North America-Caribbean PBZ, two microplates have been defined, Gonave and Hispaniola-Puerto Rico (Figure 2 II). A continuous northern strike-slip fault bordering both microplates runs from the northern coast of Haiti and the Bartlett-Cayman [Oriente] fault zone, Cibao valley of northern Hispaniola, Septentrional fault zone to Puerto Rico island slope and Puerto Rico trench.

The strike-slip fault type appears in the Northern of Caribbean region and constitutes the northern boundary of the Caribbean plate; it includes Motagua, Chixoy-Polochic, Swan, and Oriente (Figure 2 II). The main function of such system faults is to accommodate horizontal extrusion in zones of continental collision, and to serve as an agent for boundary-parallel slip between obliquely convergent oceanic and continental plates. At the western edge of this region, the Swan Islands fault zone, with left lateral strike-slip motion, defines the plate boundary. This fault zone terminates at the southwestern edge of the Cayman spreading center. Following this is the Morant trough, which is an active pull-apart basin between Haiti and Jamaica of $\sim 60 \mathrm{~km}$. This is a submarine structure that limits rates of movements on the aforementioned fault zone, the Enriquillo-Plantain Garden. Further to the east, the Mona Canyon is a narrow, deep depression in the Caribbean Sea in northwestern Puerto Rico. It is part of the inner wall of the Puerto Rico trench and is related with normal faults. All this suggested that an E-W extension process occurs here. The Muertos trough is an EW striking bathymetric feature of $\sim 5 \mathrm{~km}$ depth to the south of Puerto Rico and the Dominican Republic. Between Puerto Rico and the Virgin Islands [north of the Lesser Antilles] is the ENE-trending Anegada Passage.

On the other side, the plate boundary between Caribbean and North American plates in the north-western region is located near the Pacific trench [with the active left-lateral sense Motagua fault and the Cayman trough] (Figures 1 II, 2 I and 2 II). This is an active region in which the seismicity is shallow $[\mathrm{h} \leq 70 \mathrm{~km}]$. The Middle America Trench delineates quite well a subduction zone where the Caribbean plate is underthrust by the Cocos plate. Near to Mexico and Guatemala, a triple junction of the three aforementioned plates is formed. Farther to the south, near the northeast of Panama and Colombia, the boundary between the South American, Caribbean, and Cocos plates is much more complex [forming other triple junction]. There is a mix of a strike-slip fault system with underthrust fault systems. A weak subduction process is located around Panama. In the Colombia-Ecuador region appears the subduction of the Nazca plate under the South American plate. As we mentioned before, the Central America subduction zone is not uniform based on different points of view. The volcanic information confirms this situation, and the seismicity permits us to establish at least four distinct segments.

The Southern Caribbean region is characterized as a deformed belt with Panama, Colombia and Venezuela along its border. The contact between the South American and Caribbean plates is defined as a PBZ. It can be divided in the area around Venezuela into at least seven segments, all of these with clear east-west trending belts, constituting a transpressive boundary with a combination of strike-slip faults and thrust belts that produce a positive flower structure.

The Hess Escarpment is a great feature of the Caribbean seafloor, with a defined NE strike (Figure 2 III). It is located from South America to Hispaniola. Another important structure is the Beata Ridge. It extends $400 \mathrm{~km}$ south from Beata Cape, Hispaniola, dividing the Caribbean into the Colombia [with crustal thickness of $<10 \mathrm{~km}$ ] and Venezuela [with crustal thickness of $10 \mathrm{~km}$ ] basins. It is a $\sim 20 \mathrm{~km}$ Cretaceous volcanic plateau that goes nearly $10 \mathrm{~km}$ 
into the Aruba area. To the west, the ridge is bound by a steep escarpment with a regional slope of $15^{\circ}-25^{\circ}$ that rises $2,500 \mathrm{~m}$ above the Colombia abyssal plain. To the east, the ridge drops down to the centre of the Venezuela basin in a series of steps. The Beata Ridge is an oceanic plateau whose edges have been reactivated by differential motion between the two aforementioned structures. Hispaniola and Puerto Rico are separated from the Venezuela Basin by the Muertos trough.

\section{I}

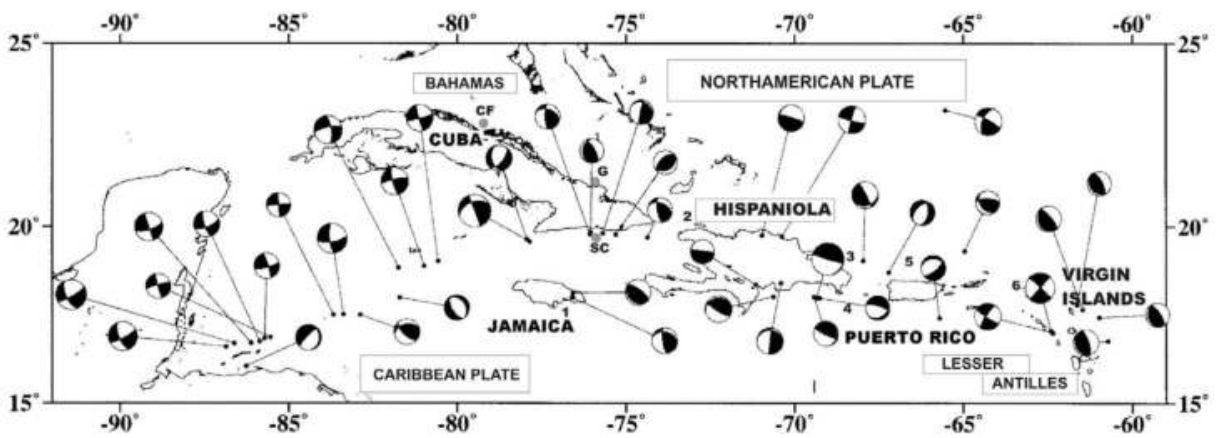

[Tsunsamigenic zones ( $1=$ Jamaica; $2=$ Haiti; $3=$ Dominican Republic; $4=$ Muertos trough; $5=$ Puerto Rico trench; $6=$ Virgin Islands).]

Fig. 2. I.- Selection of the focal mechanisms in the northern Caribbean and the tsunamigenic zones in the northeasterrn Caribbean.

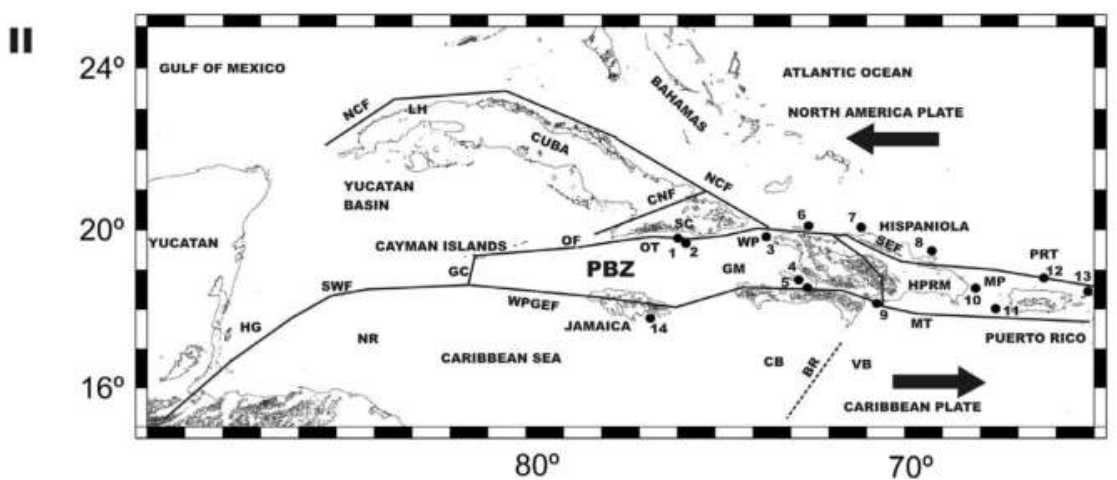

[Heavy black arrows (sense of plate movements); black lines $=$ main fault systems (CNF= Cauto-Nipe, $\mathrm{NCF}=$ Nortecubana, $\mathrm{HG}=$ Honduras-Guatemala, $\mathrm{OF}=$ Oriente, $\mathrm{SEF}=$ Septentrional, $\mathrm{SWF}=\mathrm{Swan}$, WPGEF $=$ Walton-Platain Garden-Enriquillo); other structures $(\mathrm{CB}=$ Colombia basin, $\mathrm{MP}=\mathrm{Mona}$ Passage, MT: Muertos trough, NR= Nicaragua Rise, OT= Oriente trough, PBZ= Plate Boundary Zone, $\mathrm{PRT}=$ Puerto Rico trench, $\mathrm{VB}=$ Venezuela Basin, $\mathrm{WP}=$ Winward Passage); localities (LH= La Habana, $\mathrm{SC}=$ Santiago de Cuba); Strongest earthquakes (Black circle $=$ epicenter including year (magnitude): $1=$ $1766(6.8), 2=1852(6.4), 3=1887(7.9), 4=1770(7.5), 5=2011(7.0), 6=1842(8.2), 7=1897(7.5), 8=1946(7.8), 9=$ 1673(7.5), $10=1943(7.5), 11=1918(7.3), 12=1887(8.0), 13=1867(7.3), 14=1692(7.5)$.

Fig. 2. II.- Simplified tectonic map of the Caribbean with the strongest earthquakes in the northeastern Caribbean. 


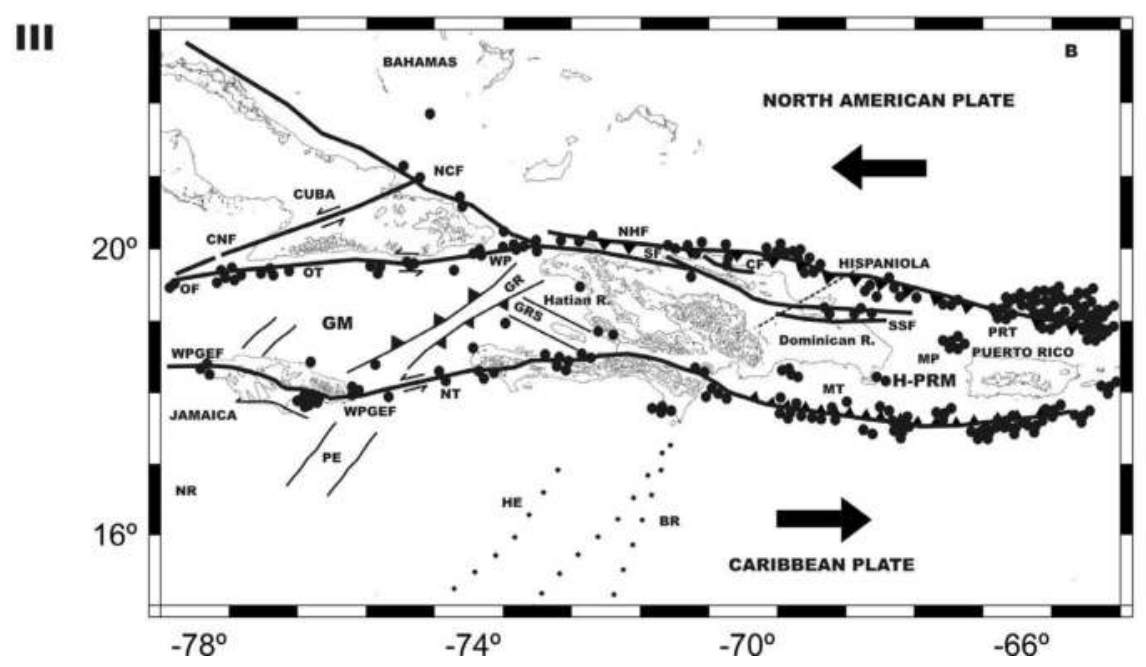

[Heavy black arrows (sense of plate movements); black points (epicentres); black lines= main fault systems $(\mathrm{CF}=\mathrm{Camú}, \mathrm{CNF}=$ Cauto-Nipe, $\mathrm{HG}=$ Honduras-Guatemala, $\mathrm{NCF}=$ Nortecubana, NHF= North Hispaniola, $\mathrm{OF}=$ Oriente, $\mathrm{SF}=$ Samaná; $\mathrm{SEF}=$ Septentrional, $\mathrm{SWF}=\mathrm{Swan}, \mathrm{WPGEF}=$ Walton-Platain Garden-Enriquillo); the drawing of the points outlines the structure BR= Beata Ridge, HE= Hess Escarpment; passages ( $\mathrm{MP}=\mathrm{Mona}, \mathrm{WP}=$ Windward); islands (Cuba, Hispaniola, Jamaica, Puerto Rico); microplates $(\mathrm{GM}=$ Gonave, HPRM= Hispaniola-Puerto Rico); troughs (MT= Muertos, NT= Navassa, $\mathrm{OT}=$ Oriente, $\mathrm{PRT}=$ Puerto Rico); other structures $(\mathrm{CB}=$ Colombia Basin, $\mathrm{GR}=$ Gonave Ridge, $\mathrm{GRS}=$ Gonave).]

Fig. 2. III.- Tectonic map of the central - northeastern Caribbean.

The Lesser Antilles volcanic arc results from a subduction of the American plate under the Caribbean plate. It runs from the Anegada Passage [to the north] to South America. The volcanic arc draws a curve of $\sim 850 \mathrm{~km}$ in length and a $450 \mathrm{~km}$ radius. It is considered to have a high seismic risk because of its active geodynamic context. Movements of two of the aforementioned plates control the tectonic, volcanic, and seismic activities in the region. Each plate is also the seat of a network of major faults. The north and the east of the Caribbean correspond to an active margin, related to the subduction of the American plate under the Caribbean plate [ $2 \mathrm{~cm} /$ year]. The subduction angle is stronger in the centre of the $\operatorname{arc}\left[60^{\circ} \mathrm{N}\right.$, Martinique] than in the north $\left[50^{\circ} \mathrm{N}\right.$, Guadeloupe $]$ and in the south. This type of subduction is considered as an intermediate type between the Mariana type [low speed of convergence with weak subduction earthquakes], and the Chile type [high speed of convergence with strong subduction earthquakes [M $>8]]$.

\section{Seismicity and focal mechanisms in the northern Caribbean}

We determined 141 earthquakes with $\mathrm{M} \geq 6.4$ that have affected the Caribbean territory (Tables 14 and 15). This is a significant magnitude for the region if we take in consideration the seismic history. Table 16 has the first seismic reports in the Caribbean region. The stress and strain distributions deduced from focal mechanism analyses infer a small N-S to NE-SW convergent component associated with the major strike-slip motion of the Caribbean and North American plates (Figure 2 I). Northern Hispaniola's tectonic regime is 
transpressional, with the main compressive stress axis being sub-horizontal and striking about $\mathrm{N} 50^{\circ}$.

\begin{tabular}{|c|c|}
\hline Magnitude & Total \\
\hline $6,4-7,0$ & 75 \\
\hline$>7,0-7,5$ & 48 \\
\hline$>7,5$ & 19 \\
\hline
\end{tabular}

Table 14. Earthquakes by magnitude range.

\begin{tabular}{|c|c|c|c|}
\hline Time period & Total & Time period & Total \\
\hline $1940-1960$ & 16 & $1981-2000$ & 35 \\
\hline $1961-1980$ & 22 & $2001-2011$ & 16 \\
\hline
\end{tabular}

Table 15. Earthquakes of $M \geq 6,4$ by time period.

\begin{tabular}{|c|c|c|c|c|c|}
\hline Year & Site & Year & Site & Year & Site \\
\hline 1502 & Santo Domingo & 1530 & Venezuela & 1657 & Martinique Is. \\
\hline 1516 & Panama & \multirow[t]{2}{*}{1538} & Honduras & $1663 ?$ & Puerto Rico \\
\hline 1526 & Guatemala & & El Salvador & 1667 & Jamaica \\
\hline \multirow[t]{2}{*}{1528} & Cuba & 1566 & Colombia & 1669 & Guadaloupe Is. \\
\hline & Nicaragua & 1608 & Costa Rica & & \\
\hline
\end{tabular}

Table 16. First reports of Caribbean earthquakes.

In the Northern Caribbean, the most intense seismicity is located around restraining bends such as southern Cuba and northern Hispaniola (Figure 2 II). In particular, the seismicity of Hispaniola is plainly justified by its geodynamic position, both with respect to the frequency of occurrence and to the magnitude of the seismic events. Thus, in a catalog of the 1502-1971 period, there appear 15 intensity VII, 12 intensity VIII, and 10 intensity IX earthquakes, and one earthquake of $\mathrm{X}$ degrees of intensity [MSK scale], which the authors place in two independent bands to the north and south of Hispaniola. On the other hand, three bands of seismic activity were described, one to the north and two in a NW transversal direction, of which the one found in the southeastern area corresponds to deep earthquakes. This zone was studied and recognized much earlier. Additionally, eight active zones have been described in the northeastern Caribbean. However, five of them have not been associated with seismicity in the last 40 years. On the basis of this data and statistical treatment, two seismogenic bands were described to the north and the south, and one transversal band in a NW direction. The seismic potential for the Cuba-Jamaica-Hispaniola sector was later defined, and it was determined that the strongest events $[\mathrm{M}=8.0]$ could occur in two sectors in the northern region, in Haiti and the Dominican Republic. Figure 2 II shows some of the strongest earthquakes in the Caribbean area, all occurring within the PBZ.

A large earthquake [Ms=7.8] occurred in the northeastern Hispaniola on August 4, 1946. The epicenter was at $15 \mathrm{~km}$ off the coast in the South Samna Bay. It was located $\sim 25 \mathrm{~km}$ to the south of the Septentrional Fault Zone. There have been some interesting discussions about this earthquake and its focal mechanism. Nevertheless, we consider that the north central part of the Caribbean region is tectonically well-characterized by strain partitioning above a southsouthwest dipping thrust interface along the top of the underthrust North American slab below the Caribbean plate. The aforementioned earthquake in the city of Julia Molina [north- 
eastern of Dominican Republic] produced a maximum intensity value of $\mathrm{X}$ degrees [Mercalli scale]. In the vicinity of the Samana-Sanchez-Moca-Santiago-Puerto Plata localities, the value was IX degrees. In addition, the first village suffered the effects of a tsunami, but they were minimal. Southeast of Julia Molina [in the Matanzas village], only $3 \mathrm{~km}$ away, damage was heavier and caused 100 fatalities. No earthquake faulting was detected. According to the prepared isoseismal map, it is possible to assume that the epicenter lay to the NE of Julia Molina, about $50 \mathrm{~km}$ offshore. This tsunami affected Puerto Rico.

Reports of the 1751.10 .18 earthquake [M 8] showed large and extensive damage only to the south of Hispaniola, which suggests that the earthquake occurred along the southern margin of Hispaniola-Puerto Rico. A tsunami was triggered that affected Hispaniola. Also, the 1984.06.24 earthquake [M=6.7] occurred south of Hispaniola beneath the San Pedro Basin, and shallow earthquakes occurred between Hispaniola and Puerto Rico. These events show the seismic activity of the Muertos trough and suggest that these islands lie on two separate microplates.

A portion of the Caribbean plate that is seismically active is oriented NNE, and a dip to the NNE is subducted below the North of Colombia. Thus, the north of Venezuela is part of the boundary between the Caribbean and South American plates. The contact zone has produced a system of dextral strike-slip faults with an E-W strike along a $150 \mathrm{~km}$ mountainous belt. It is formed by the mountain systems of the Venezuelan Andes and the Central and Eastern Cordilleras, termed the Oca-Ancon-Bocono-San Sebastian-El Pilar fault system. The Venezuela East has two distinct tectonic regimes, namely, the dextral strike-slip system El Pilar and the subduction zone between the NW of the region and the Lesser Antilles Islands. The seismicity of the Venezuelan territory is superficial and is concentrated at a $\sim 40 \mathrm{~km}$ depth, except for that detected in the subduction zone of the NE at $\sim 20-120 \mathrm{~km}$. The magnitudes are low [M $\leq 5]$, yet we point out a strong event $[\mathrm{Mb}=7.7]$ on March 26, 1812, that caused $\sim 20,000$ deaths. In addition, Venezuela has had at least five strong earthquakes [Ms>8.4] that have produced tsunamis.

\section{Tsunamis in the Caribbean}

References used for this section are: Cotilla, 2007; Cotilla and Córdoba, 2010; Cotilla et al.,1998; Grindlay et al., 2005; Hillebrandt-Andrade and Huerfano Moreno, 2004; Lander et al., 2002; McNamara et al., 2005; and Rubio, 1982;.

Within the Caribbean region, there are multiple fault segments and submarine features that could be sources for earthquakes and landslides, triggering tsunamis. The perimeter of the Caribbean plate is bordered by no fewer than four plates [the North American, South American, Cocos, and Nazca]. Subduction occurs along the eastern and north-eastern margins of the Caribbean plate. Normal, transform, and strike-slip faulting characterize the northern South American, eastern Central American, the Cayman Ridge, and the northern PBZ. All of these elements are in direct relation to the focal mechanisms determined in the region (Figure 2 I). In the north-eastern Caribbean, the Puerto Rico trench lies roughly parallel to, and about $130 \mathrm{~km}$ off of, the northern coast of Puerto Rico and is about $900 \mathrm{~km}$ long and $100 \mathrm{~km}$ wide. At $8,350 \mathrm{~m}$ below the surface, it is the deepest trench in the vicinity of the Atlantic Ocean. The Hispaniola trench parallels the north coast of the Dominican Republic and Haiti and is $550 \mathrm{~km}$ long and 4,500 $\mathrm{m}$ deep. The Virgin Islands and Anegada troughs cut across the Antilles arc between the northern Virgin Islands and St. Croix and the Lesser Antilles. The Muertos trough, $\sim 5,000 \mathrm{~m}$ deep, is an E-W striking bathymetric feature south of Puerto Rico- 
Hispaniola. Tsunamis could be generated along these structures, but the direction of the waves would depend on many factors, including where the earthquake occurred.

Examining tables 10 and 16 confirm that the first European settlements [16 ${ }^{\text {th }}$ century] in America reported earthquakes and tsunamis. Considering the year of arrival of the first European settlers to the Caribbean as the initial time of tsunami observations we get a rate of 0.12 tsunamis/yr, while the rate for the Pacific Ocean is 393 tsunami /1,327 yr, or 0.30 tsunamis/yr. Tsunamis have been documented in the Caribbean [1688-2011]. Rubio (1982) lists 16 tsunamis associated with earthquakes, the strongest [Ms=7.8] of which occurred on August 4, 1946, in the northeast of Hispaniola. A list of 38 Caribbean tsunamis can be found at $\{$ http://webserver2.ineter.gob.ni/geofisica/tsunami/tsu-caribe-list.html\} [published by Caribbean Tsunami Awareness, Florida Inst. Technology, Univ. Publ. EN-158-399]. Of the 38 events, three are stated to have occurred in Cuba [1755, 1775, and 1932]. Table 17 gives 5 reports on Cuba, following Rubio (1985). The probability of tsunami occurrences in Cuba is very low, because of certain focal mechanisms and the arrangement of the seismogenic marine structures that surround the island. Interestingly, the tsunami caused by the earthquake on 1755.11.01 in Lisbon was perceived in Santiago de Cuba: "The severe earthquake of 1755 was accompanied by a sea-wave which almost completely inundated the town". A comparison of data using two sources appears in table 18.

We would like to suggest that there is an error in the assigned magnitude [8.1] of the 1939 earthquake in Cayo Frances (Figure 2 I). This region belongs to the North-Center of Cuba, and it has never had such a high magnitude earthquake. Indeed, an earthquake of that magnitude has never even occurred in the south-eastern part of the island [Santiago de Cuba], which is the most active. As an example, we point to the 1914.02.28 earthquake [21.30 $\mathrm{N} / 76.20 \mathrm{~W} ; \mathrm{h}=50 \mathrm{~km} ; 05: 19 ; \mathrm{M}=6.2]$; this was the strongest earthquake in the north coast of Cuba [in the vicinity of Gibara-Holguin] (Figure 2 I).

\begin{tabular}{|l|c|c|c|}
\hline \multicolumn{1}{|c|}{ Region } & Total & Largest & Date \\
\hline Cuba & 5 & & $1770.06 .03 ; 1842.05 .07$ \\
\hline Haiti & 10 & 2 & $1946.08 .04 ; 1946.08 .08$ \\
\hline Dominican Republic & 4 & 2 & 1918.10 .14 \\
\hline Jamaica & 8 & 4 & $1692.06 .07 ; 1780.10 .03 ; 1881.08 .12 ; 1907.01 .04$ \\
\hline Puerto Rico & 3 & 1 & $1690.04 .16 ; 1867.11 .18$ \\
\hline Virgin Islands & 3 & 2 & \\
\hline
\end{tabular}

Table 17. Tsunamis in the Northern Caribbean (Lander et al., 2002).

\begin{tabular}{|c|c|l|c|c|l|}
\hline $\mathbf{N}^{\mathbf{0}}$ & \multicolumn{1}{|c|}{ Date } & \multicolumn{1}{|c|}{ Site } & Rubio & Lander & \multicolumn{1}{|c|}{ Note } \\
\hline 1 & 1755.11 .01 & Santiago de Cuba & $\mathrm{X}$ & $\mathrm{X}$ & Teletsunami \\
\hline 2 & 1766.06 .12 & Santiago de Cuba & & $\mathrm{X}$ & Cotilla, 2007 (no agree) \\
\hline 3 & 1775.12 .18 & Santiago de Cuba & $\mathrm{X}$ & $\mathrm{X}$ & \\
\hline 4 & 1852.07 .17 & Santiago de Cuba & $\mathrm{X}$ & $\mathrm{X}$ & Cotilla, 2007 (no agree) \\
\hline 5 & 1931.10 .01 & Playa Panchita-Rancho Veloz & & $\mathrm{X}$ & Cotilla, 2007 (no agree) \\
\hline 6 & 1932.02 .03 & Santiago de Cuba & $\mathrm{X}$ & $\mathrm{X}$ & Montelieu, 1933 (no agree) \\
\hline 7 & 1939.08 .04 & Cayo Frances & & $\mathrm{X}$ & Cotilla, 2007 (no agree); Ms5,6 \\
\hline
\end{tabular}

Table 18. Tsunamis in Cuba according to two sources. 
On the western Caribbean coasts, tsunamis are concentrated near the Honduras Gulf, which includes the coasts of Belize, Guatemala, and Honduras, and on the Costa Rica-Panama coasts (Tables 19 and 20). They are related to seismic activity in North American-Caribbean and Panama Deformed Belt tectonic environments, respectively. The majority of the tsunamis have been small, causing little damage. However, along the Pacific coast many tsunamigenic earthquakes are inland or close to the coast and this might have reduced the height of the sea waves.

\begin{tabular}{|c|c|c|c|c|c|c|c|}
\hline $\mathbf{N}^{\mathrm{o}}$ & Date & Coordinates & Ms / H(km) & $\mathrm{N}^{0}$ & Date & Coordinates & Ms / H(km) \\
\hline 1 & 1798.02 .22 & $10,2 \mathrm{~N} / 82,9 \mathrm{~W}$ & & 5 & 1904.12.20 & $09,2 \mathrm{~N} / 82,8 \mathrm{~W}$ & $7,3 / 25$ \\
\hline 2 & 1822.05 .07 & $09,5 \mathrm{~N} / 83,0 \mathrm{~W}$ & $7,6 /-$ & 6 & 1916.04.26 & $09,2 \mathrm{~N} / 83,1 \mathrm{~W}$ & $6,9 /-$ \\
\hline 3 & 1873.10 .14 & $10,2 \mathrm{~N} / 80,0 \mathrm{~W}$ & & 7 & 1991.04.22 & $09,6 \mathrm{~N} / 83,2 \mathrm{~W}$ & $7,6 / 20$ \\
\hline 4 & 1882.09 .07 & $10,0 \mathrm{~N} / 79,0 \mathrm{~W}$ & $7,9 /-$ & & & & \\
\hline
\end{tabular}

Table 19. Tsunamis earthquakes in the Caribbean - Central America area.

\begin{tabular}{|c|l|c|l|}
\hline $\mathbf{N}^{\mathbf{0}}$ & \multicolumn{1}{|c|}{ Region } & Verified / Possible = [Total] & \multicolumn{1}{c|}{ Comments } \\
\hline 1 & Costa Rica & $-/ 1[1]$ & \\
\hline 2 & Cuba & $2 / 3[5]$ & Cotill1a, 2007 (no agree) [0] \\
\hline 3 & Dominican Republic & $2 / 1[3]$ & \\
\hline 4 & Guiana (British) & $-/ 1[1]$ & \\
\hline 5 & Haiti & $4 / 6[10]$ & \\
\hline 6 & Honduras (western area) & $1 / 1[2]$ & \\
\hline 7 & Jamaica & $2 / 6[8]$ & \\
\hline 8 & Panama (western area) & $1 / 4[5]$ & \\
\hline 9 & Puerto Rico & $-/ 4[4]$ & \\
\hline 10 & Venezuela & $7 / 19[26]$ & $\mathrm{M}_{\mathrm{T}}=8,1$ \\
\hline 11 & Virgin Islands & $11 / 8[19]$ & \\
\cline { 2 - 4 } & Total & $\mathbf{3 0 / 5 4}[\mathbf{8 4}]$ & $\mathbf{2 8 / 4 0 [ 5 8 ]}$ \\
\cline { 2 - 4 }
\end{tabular}

Table 20. Local tsunamis in the Caribbean.

The Caribbean region has not had a great tsunamigenic earthquake. However, most of the tsunamis [58] occurred in it, and at least two teletsunamis were triggered from far away by earthquakes [near the coasts of Portugal and the Indonesia Krakatoa Volcano] (Table 18). These represent only $10 \%$ of the world's oceanic tsunamis. It has been estimated by authorities that they have caused the death of $\sim 9.000$ people in the region. It was stated that the Caribbean region has been affected by tsunamis from both near and far sources. In particular, the areas with the most tsunamis are in the West [Middle America] and East [Lesser Antilles]. These areas have direct contact with the Pacific and Atlantic Oceans, respectively. These edges have troughs, volcanoes, and undersea sediments with defined subduction profiles. The subduction profile of the eastern edge of the Caribbean has a lower seismic activity than the western one and is characterized by the typical island arc. As 
explained above, these two parts have often been studied, but there are still many gaps in our knowledge to explain its geodynamic behavior.

Regional tsunamigenic sources are also present in the Caribbean. They are able to produce tsunamis but have never, based on the data presented here, greatly affected the North Caribbean. These sources are located in: 1) the southern edge of the Caribbean; 2) the eastern edge of the Caribbean; and 3) the westerner part of the Caribbean Sea. We would like to point out that tsunamis generated in Venezuela did not seriously affect the northern Caribbean. Other areas outside the Caribbean plate are the Gulf of Mexico, the South of the U.S.A., and the Bahamas Platform, these likewise do not constitute a great hazard. In addition, the Caribbean islands are also susceptible to tsunamis generated within the region and to distant earthquakes, such as the 1755 Lisbon earthquake.

According to table 16, Haiti and Jamaica are the tsunamigenic structures of the Caribbean that has the highest number of events [10 and 8]. The Hispaniola [Haiti-Dominican Republic] has 14 events, while Puerto Rico and the Virgin Islands together have six. However, taking into account the location of Puerto Rico on the Greater Antilles arc, and to the surrounding structures [Puerto Rico trench, the Anegada trough and Muertos trough, the Atlantic Ocean, and the active faults system], Puerto Rico turns out to be where the risk of tsunamis is highest in the Northern Caribbean. And looking at the focal mechanism types [thrust fault and normal fault] (Table 1) which are more inclined to generate tsunamis in the northern Caribbean, two zones must be considered, southern Hispaniola-Puerto Rico, and northern Hispaniola-Puerto Rico-Virgin Islands. These are also the zones in which the strongest earthquakes and the most important tsunamis have occurred. Thus, these zones exhibit the highest probability of tsunamis.

The recent tsunami history is quite unusual for the Caribbean. Therefore, with our experience about hurricanes and polar fronts in the tropical region, we can assume that some of these phenomena could have been reported in the last centuries [ $\left.15^{\text {th }}-18^{\text {th }}\right]$ as tsunamis. Thus, the Caribbean is historically more dangerous for cyclones, then hurricanes, and finally tsunamis, based on the frequency of occurrence. In addition, the first two phenomena cause frequent and important floods from the sea to the land. Floods are also produced with the arrival of north and south fronts. The period with the greatest probability of front occurrences is December-February, while that of cyclones and hurricanes is September-November. These situations of sea movements could have affected the first reports on tsunamis; we shall discuss this in the next section.

The area of the Caribbean Pacific has been investigated by segments according to the financial possibilities of each country involved (Figure 1 II). In general, 393 tsunamis have been accounted for, while 155 tsunamis are documented for the Atlantic area. This region being adjacent to large basin, it is clear that the danger of seismic sea waves is very high. Furthermore, the fact that strong seismic events [M $>8.5]$ occur in a range of depths, from superficial to deep, adds an element to generating local and regional tsunamis. As we indicated, the northern and southern edges of the Caribbean plate also differ in terms of contacts and movements. The northern border is more regular and homogeneous, although there are two deep troughs [Oriente and Puerto Rico] in its outline, and it has been affected by several local tsunamis and teletsunamis. Our interest is centered on the northern edge. Major tsunamis in the Northern Caribbean are indicated in table 17. Table 21 contains information about tsunamis in Venezuela (southeastern Caribbean). 


\begin{tabular}{|c|c|c|c|c|}
\hline $\mathbf{N}^{\mathbf{0}}$ & Date / Time & Coordinates & $\mathbf{M}_{\mathrm{T}} / \mathbf{I}$ (MM) & Locality \\
\hline 1 & $1530.09 .01 / 14: 30 \mathrm{UT}$ & $10,7 \mathrm{~N} / 64,1 \mathrm{~W}$ & $-/ \mathrm{X}$ & Cumana \\
\hline 2 & 1868.08 .13 & $18,5 \mathrm{~N} / 70,3 \mathrm{~W}$ & $8,5 /-$ & Rio Caribe \\
\hline 3 & 1900.10 .29 & $10,9 \mathrm{~N} / 64,1 \mathrm{~W}$ & $8,4 /-$ & Cumana \\
\hline 4 & 1906.01 .31 & $2,4 \mathrm{~N} / 79,3 \mathrm{~W}$ & $8,9 /-$ & Cumana \\
\hline 5 & 1929.01 .17 & $10,0 \mathrm{~N} / 64,0 \mathrm{~W}$ & $8,1 /-$ & Cumana \\
\hline
\end{tabular}

Table 21. Strongest earthquakes with tsunamis in Venezuela.

\section{Final remarks}

It is first necessary to be clear about two concepts: 1) a hazard is a potentially perilous event; and 2) the risk is the probability that the hazard will occur repeatedly and affect a locality, region, and population. Included in this last concept is magnitude, frequency of occurrence, and exposure. Therefore, these multiple parameters present a large problem to the scientists when attempting to estimate the tsunami risk. This is also highly complex because of the technical, economic, and social factors that are additionally involved. Given these elements, it is necessary to collect all available data, and the analyses performed should be used to initially generate a basic scheme of tsunami risk. After that, it is necessary to continue localizing those areas and zones with the higher hazard and risk potential. The results obtained should be first discussed with other specialists and public officials before being transmitted to the general public. Afterwards, such document can be used as "the guidelines for correct tsunami response and community preparedness from local emergency managers".

\begin{tabular}{|c|c|c|c|c|}
\hline $\mathbf{N}^{\mathbf{0}}$ & Date & Category & Denomination & Damages \\
\hline 1 & 1844.10 & 5 & La Tormenta de San Francisco de Asís & $>100$ deaths \\
\hline 2 & 1846.10 & 5 & La Tormenta de San Francisco de Borja & $>100$ deaths \\
\hline 3 & 1870.10 & 5 & San Marcos & $>800$ deaths \\
\hline 4 & 1910.10 & 5 & Huracán de los Cinco Días & $>100$ deaths \\
\hline 5 & 1926.10 & 5 & Huracán de 1926 & $\sim 600$ deaths \\
\hline 6 & 1930.09 & 4 & San Zenón & $\sim 6.000$ deaths \\
\hline 7 & 1932.11 & 5 & Huracán de Santa Cruz del Sur & $\sim 3.500$ deaths \\
\hline 8 & 1944.10 & 5 & Huracán de 1944 & $\sim 300$ deaths \\
\hline 9 & 1963.10 & 5 & Flora & $\sim 2.000$ deaths \\
\hline 10 & 1966.09 & 4 & Ines & Unknown \\
\hline 11 & 1979.08 & 5 & David & $\sim 4.000$ deaths \\
\hline 12 & 1988.09 & 4 & Gilbert & Unknown \\
\hline 13 & 1992.08 & 5 & Andrew & $\sim 29$ deaths \\
\hline 14 & 1998.09 & 3 & George & Unknown \\
\hline 15 & 2001.11 & 4 & Michelle & Unknown \\
\hline 16 & 2004.09 & 4 & Ivan & $\sim 20$ deaths \\
\hline 17 & 2005.07 & 5 & Dennys & Unknown \\
\hline 18 & 2008.09 & 5 & Paloma &
\end{tabular}

Table 22. Some hurricanes affected Caribbean. 
The Caribbean region is well-known for its hurricanes and much less so for tsunamis. Historically, a significant amount of deaths have been connected not only with tsunamis in the region (Tables 9 and 22). In particular, the northern Caribbean distinguishes some tsunami sources: 1) Mona Canyon; 2) Puerto Rico trench; 3) Mona trench; 4) Septentrional fault; 5) Pedro Bank; and 6) Western Caribbean Sea (Figure 2 III). The Caribbean is a region of islands, and it can be considered potentially from the tsunami hazard point of view (Table 23). Here in the islands exists a strong coastal culture. There are a lot of residential buildings, hotels, large tourism activities areas, etc. In general, the population has increased greatly, as has the risk for natural hazards [hurricanes, earthquakes, etc.]. Therefore, the region is vulnerable, and several programs need to be taken into consideration to attempt to minimize any future possible disasters.

\begin{tabular}{|l|c|c|}
\cline { 2 - 3 } \multicolumn{1}{c|}{} & Probable / Verified & Note \\
\hline Tsunamis & $18 / 19$ & Lisbon $(1755,1761)$, Krakatoa $(1883)$ \\
\hline Teletsunamis & $3 / 3$ & \multicolumn{1}{c|}{} \\
\hline Total & 37 &
\end{tabular}

Table 23. Other data from the Caribbean catalog.

We know that the Caribbean region is made up of poor developing countries. It is also known that tsunami defenses that could protect the inhabitants and their properties could be quite costly. Additionally, the cultural behaviors and the scholarly resources are very limited. A first logical and economic option is to leave a strip of land by the sea that is to be occupied only by construction necessary for the port, bay, and structures that require close proximity to the sea, such as beach clubs, warehouses, etc. The width of this strip would depend on the wave's height at the coast and how far it would advance inland.

The occurrence of natural disasters is difficult to predict based on observations from a restricted period of time. Ancient writings are important sources of information but are restricted either locally or historically. The possibility exists, however, that large-scale tsunamis are recorded in coastal sediment deposits. Disturbances of normal sedimentary processes by a tsunami may remain in lacustrine deposits and be represented by unusual sedimentary layers. These tasks fall to scientists and take time and money.

As we said before, the Puerto Rico-Virgin Islands region (Figure 2 III), which should be considered to be one of highest risk areas in the Caribbean, has around 4 million inhabitants. It was affected at least by large earthquakes of Hispaniola [08.09.1615], Virgin Islands [20.04.1824, 18.11.1867, 17-09.1869], and Mona Passage [28.07.1943] (Figure 2 II). Some tsunamigenic earthquakes have occurred in that region in the last few hundred years, such as the 1867 Virginia Islands and 1918 Puerto Rico quakes. In this sense, Grindlay et al. (2005) stated that the northern Caribbean is under a high risk of tsunami, while Rubio (1982) takes the opposite side. Based on the recommendations by Rubio, Cuba should not be considered to be at risk for tsunamis when planning works in the coastal zones. However, the UNESCO IOC, U.S. Natural Tsunami Hazard Mitigation Program and Warning Coordination Subcommittee organized the Exercise Pacific Wave 08 from October 28-30, 2008. Additionally, they prepared the Exercise Caribbean Wave 11/Lantex 11 on March 23, 2011, because they consider that tsunamis represent a significant hazard to society in this area.

Specifically studying a given coastal area to assess the tsunami risk is quite a complex task. It involves some variables that are difficult to model because of their great variability, such 
as: 1) topography; 2) bathymetry; 3) shape of the coast type; 4) strike of sea wave movements; 5) earthquake magnitude; 6) focal depth; and 7) focal mechanism. This is more complicated when considering the periodicity of the sea waves after the event has occurred. Currently, the velocity differences between the seismic and tsunami waves are used for tsunami warning systems. We mentioned before that the velocity of a tsunami is very fast for an ocean wave $[0.2 \mathrm{~km} / \mathrm{s}$ for a water depth of 5,000 m], but this is still considerably slower than seismic waves [5-10 km/s]. Thus, there is time to issue a tsunami warning after seismic wave detection in seismological stations but before the actual tsunami arrives. The parameters used in order to judge the tsunamigenicity are seismic magnitude and focal depth.

A proven method of protecting coastal villages from the damage of tsunamis is by planting trees in front of the residential areas. A zone of arranged trees [greenbelt] cannot prevent sea water from flowing into the villages, but we can expect it to effectively dissipate the energy of the incident waves of the tsunamis and to reduce the number of victims. In order to improve the dissipation efficiency, we should select varieties of trees that have many low branches with a high leaf density. A wide coral reef is another effective obstacle for dissipating part of the tsunami energy. The roots, trunks, and branches of mangroves are an effective defense against tsunamis and tropical storms. Also, thick rows of trees and shrubs are used to increase resistance to the sea waves on land. Stakes are even driven into the ground for this purpose. Inhabitants of a possible tsunami-inundation zone may be protected at different steps with a master emergency plan whose most important component is evacuation. It is critical that this action is very well studied and practiced with citizens. The two basic pieces of information are: 1) the arrival time of the first wave; and 2) delimitation of the inundation zone [floods]. Next, it is very important that a plan of action has been previously prepared by the local and regional authorities, together with scientists, civil defense specialists, the police and fire departments, and medical emergency teams. It is necessary to plan and locate places of refuge and evacuation routes; it is also essential to organize the community, clearly signal the escape routes and strategically place speakers and sirens, create educational programs for the population, and plan the use of the coastal land, among other things.

Table 24 contains some general recommendations to the population in order to protect again a tsunami occurrence. There are three groups of tsunami warning systems: 1) Pacific-wide system; 2) regional systems; and 3) local systems. The website http://www.usgs.gov/ science/science.php?term $=304$ contains valuable information and videos about: 1) tsunami preparedness along the U.S. West Coast; 2) tsunami preparedness in California; 3) tsunami preparedness in Oregon; and 4) tsunami preparedness in Washington. Normally, the first warning of a tsunami approaching the coast is a relatively quick withdrawal of water from the beaches. Following this, in the time interval of 5-30 minutes later, the recoil is followed by a wave capable of extending hundreds of meters inland. Thus, we can observe a rolling in and out with the resulting eddies. Estimates made in the Pacific Ocean suggest that a tsunami generated in the vicinity of the Aleutian Islands will arrive about 5 hours later to Hawaii, while one produced offshore of Chile will take about 15 hours to reach Hawaii. And studying tsunami travel times, in order to generate different charts for tsunamis in the Caribbean, has revealed that the estimated time for a complete crossing of the Caribbean is $\sim 3$ hours laterally and only 1.5 hours transversally. The experience with the 1755.11 .01 tsunami of SW Portugal shows that the sea waves arrived to the Caribbean area $\sim 7-8$ hours later. These times are long enough to be able to adequately inform the population. 


\begin{tabular}{|c|l|}
\hline $\mathbf{N}^{\mathbf{0}}$ & \multicolumn{1}{c|}{ Information / recommendation } \\
\hline 1 & $\begin{array}{l}\text { Tsunamis that strike coastal areas are almost produced by earthquakes. They can } \\
\text { be generated near or far away of the place where you are situated. }\end{array}$ \\
\hline 2 & Low coast areas may be affected by tsunamis. \\
\hline 3 & Tsunami can move faster than any person. \\
\hline 4 & The water near the shore can be receding before to the arrival of a tsunami. \\
\hline 5 & $\begin{array}{l}\text { The force and energy of a tsunami are enormous. Tsunamis may transport heavy } \\
\text { rocks, boats and other debris inland hundred of meters. }\end{array}$ \\
\hline 6 & The occurrence of tsunamis can be at any time. \\
\hline 7 & Tsunamis can travel up rivers and streams from the ocean. \\
\hline
\end{tabular}

Table 24. Some general information and recommendations.

In general, the energy carried by a tidal wave, when it originates in an earthquake, is small in relation to the tremor that generate it. It has been found that the ratio between the energy carried by a tsunami and an earthquake is between 0.1 and 0.01 . This is, however, an important level of energy. Different specialists have argued that the Indian Ocean, the Atlantic Ocean, and the Caribbean Sea have a tsunami [with a $10 \mathrm{~m}$ wave height] return period of 1.000 years. However, for the Hawaiian Islands, the value is only 200 years.

A wealth of information about tsunamis can be found in some websites:

1. The institutions of the National Weather Service: NWS Tsunami Centers of: (a) the West Coast Alaska Tsunami Warning Center [WC/ATWC], (b) the Richard H. Hagemeyer Pacific Tsunami Warning Center [PTWC], and (c) the International Tsunami Information Center [ITIC] are located at the website http://tsunami.gov/;

a. This institution provides tsunami warning guidance for all U.S. coastal states, except Hawaii, and the Canadian coastal provinces;

b. Tsunami warning to Hawaii and the countries in the Pacific and Indian Oceans, and Caribbean Sea, are supported by the PTWC;

c. ITIC is operated on behalf of the intergovernmental Oceanographic Commission of UNESCO in order to coordinate the tsunami warning and mitigation systems globally;

2. The Tsunami Society [International Journal: Science of Tsunami Hazards $\{\mathrm{STH}\}$ Mitigating the impact of tsunami disasters through research and dissemination of knowledge; ISSN: 8755-6839]. http://www.tsunamisociety.org/

3. Tsunami data resources [NGDC Tsunami Database; Tsunami Field Survey Photographs; Atlas of Canada; Tsunamis; Centro International de Tsunamis] are included here:

4. http://www.geophys.washington.edu/tsunami/miscellaneous/relsites.html

5. The ITIC [International Tsunami Information Centre] located in Honolulu since November 1965, under the intergovernmental Oceanographic Commission of the UNESCO, has the following address: http://www.prh.noaa.gov/itic/

6. The National Oceanic and Atmospheric Administration-Pacific Marine Environmental Laboratory [NOAA Center for Tsunami Research], which has a primary task of developing methods to reduce tsunami hazards and protect life, appears at the following address: http://www.pmel.noaa.gov/tsunami/

7. The preliminary catalog of tsunamis occurring in the Pacific is located at: http://www.soest.hawaii.edu/Library/Tsunami\%20Reports/Iida_et_al.pdf. 
The study of occurrence of cyclones and hurricanes in the Caribbean region indicates that there have been 108 events during the June-November season [1785-1984], of which 14 were high intensity hurricanes (Table 23). The surf factor is conditioned mainly by synoptic situations [hurricanes and polar fronts-south fronts]. Thus, we can present three examples for Cuba: 1) 1932 [high sea level of Santa Cruz de Sur, South-Central Cuba]; 2) 1988 [hurricane Gilbert, with wave heights of $12 \mathrm{~m}$, considered to be the most intense hurricane of the century, with a minimum pressure of $880 \mathrm{Mb}$ and a wind speed of $85 \mathrm{~m} / \mathrm{s}]$; and 3) 1961, 1979 and 1993 [tropical storms with wave heights of $5 \mathrm{~m}$ in the Caribbean].

\section{Conclusions}

Tsunami is a Japanese word meaning "harbor wave". It is a set of gravity waves propagating in seawater away from an important disturbance of the sea floor, such as an earthquake, a submarine volcano, or a submarine landslide. These phenomena can cause great levels of destruction and loss of life in coastal regions since waves can transport large heavy blocks [tens of tons] hundreds of meters inland. In island arcs [such as the Caribbean], the oceanic lithosphere underthrusts beneath a continent when a large earthquake occurs. The continental lithosphere is dragged with the descending oceanic type slab prior to the earthquake occurrence. With this scope, UNESCO IOC, U.S. Natural Tsunami Hazard Mitigation Program and Warning Coordination Subcommittee prepared the Exercise Pacific Wave 08, on October 28-30, 2008. Additionally, they prepared the Exercise Caribbean Wave 11/Lantex 11, on March 23, 2011, because they consider that tsunamis represent a significant hazard to the society.

The Caribbean region is better known for its hurricanes and less so for its tsunamis. Nevertheless, the amount of deaths $[\sim 9,000]$ historically connected to tsunamis in the region is very important. In fact, $\sim 120$ tsunamis have been well documented. The sea waves generated by teletsunamis, such as that the one caused by the 1755.11 .01 earthquake in SW Portugal, took $\sim 7-8$ hours to arrive. In the northern Caribbean, there are some tsunamigenic sources: 1) Mona Canyon; 2) Puerto Rico trench; 3) Mona trench; 4) Septentrional fault; 5) Pedro Bank; and 6) Western Caribbean Sea. From our point of view, the second is the area of highest hazard, and the island of Puerto Rico is under the greatest risk.

\section{Acknowledgment}

The help provided by the library officials Gema de Andrés Ramallo and Lucía Amparo Prieto Fernández of the Universidad Complutense de Madrid was quite important. All figures were drafted by Amador García Sarduy. The Física de la Tierra, Astronomía y Astrofísica 1 Departamento provided technical and support facilities [Salvador Crespillo Maristegui and Francisco José Sánchez Dulcet]. We used the Harvard CMT catalog and the CMT software of Wessel and Smith, 1991. Financial support came in part from the projects TOPOIBERIA (CONSOLIDER 52Q6016), CTM 2006-13666-C02-02, CTM 2008-02955E/MAR, GR35/10-A/910549, and 41-SISMO-HAITI.

\section{References}

Bryant E. Tsunami: The underrated hazard. Cambridge University Press, 2001.

Cotilla M.O. Un recorrido por la Sismología de Cuba. Editorial Complutense, Madrid, 2007. ISBN 97-8-47-491827-4 (in Spanish). 
Cotilla M.O. and Álvarez J.L., 1998: Esquema de regionalización del potencial de amenaza geológica en Cuba. Revista Geofísica, 49:48-85 (in Spanish).

Cotilla M. and Córdoba D., 2011: Análisis morfotectónico de la Isla de Puerto Rico, Caribe. Revista Geofisica, 52:79-126 (in Spanish).

2010: Final report of the Caribbean tsunamis. In: Report of Física de la Tierra Department, Universidad Complutense de Madrid, 200p.

2009: Morphostructural analysis of Jamaica. Geotectonics, 43(5):420-441.

2007: Seismicity and seismoactive faults of Cuba. Russian Geology and Geophysics, 48(6):505522.

Cotilla M.O., Córdoba D. and Calzadilla M., 2007: Morphotectonic study of Hispaniola. Geotectonics, 41(5):368-391.

Dmowska R. and Saltzman B. (Editors). Tsunamigenic earthquakes and their consequences. Advances in Geophysics, vol. 39, San Diego, Academic Press, 1998.

Grindlay N.R., Hearne M. and Mann P., 2005: High risk of tsunami in the northern Caribbean. EOS, Trans.Amer.Geophys. Union, 86(12):121-126.

Hillebrandt-Andrade C.G. von and Huérfano Moreno V., 2004: Emergent tsunami warnig system for Puerto Rico and the Virgin Islands. In: Proceedings of the Caribbean Tsunami Workshop, NSF, PR Emergency Management, Sea Grant and the UPR, $15 p$.

Iida K. and Iwasaki T. (Editors). Tsunamis: Their science and engineering. Proceedings of the International Tsunami Symposium, Tokyo, 1981.

Internacional Tsunami Information Center (ITIC), 2004: Tsunami glossary. http://www.shoa.cl/oceano/itic/pdf-docs/glossary.html.

Lander J.F., Whiteside L.S. and Lockridge P.A., 2002: A brief history of tsunamis in the Caribbean Sea. Science of Tsunami Hazards, 20(2):57-94.

McNamara D.E., Hillebrandt C. von and Cruz Calderón G., 2005: Nueva red sísmica en la región del Caribe, Golfo de México y la costa este del Atlántico para el sistema de alerta de tsunamis. Revista Ciencia y Tecnología, 16:18-22 (in Spanish).

NOAA, 2004: National tsunami hazard mitigation program. http:/ / www.pmel.noaa.gov/tsunami/Dart.

Polet Y. and Kanamori H., 2000: Shallow subduction zone earthquakes and their tsunamigenic potential. Geophys.J.Int., 142:684-702.

Rubio M., 1982: Ocurrencia de tsunamis en el Caribe. Investigaciones Sismológicas en Cuba, 2:170-180 (in Spanish).

Satake K. (Editor). Tsunamis: Case studies and recent developments. Dodrecht, Springer, 2005.

Sauber J. and Dmowska R. Seismogenic and tsunamigenic processes in shallow subduction zones. Pure appl.geoghys (Tropical Vols., Basel, Birhäuser Verlag), 1999.

Shuto N. Tsunami intensity and disasters. In: Tsunamis in the World (Editor: Tinti S.), Dodrecht, Kluwer-Academic Publishers, 197-216, 1993.

Sieberg A. Erdebenkunde [Sieberg's scale]. Jena, Fischer, 102-104, 1923 (in German).

Titov V.V. Tsunami forecasting. In: The Sea. Vol. 15, Chapter 12, Harvard University Press, Cambridge, MA and London, England, 371-400, 2009.

UNESCO-IOC. Post-tsunami survey field guide. First edition. IOC Manuals and Guides No. 37. Paris, UNESCO, 1998. 
Weissert T.P., 1990: Tsunami travel time charts for the Caribbean. Science of Tsunami Hazard, 8(2):67-78. 


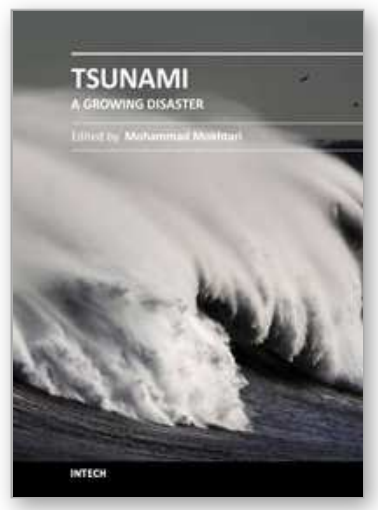

\author{
Tsunami - A Growing Disaster \\ Edited by Prof. Mohammad Mokhtari
}

ISBN 978-953-307-431-3

Hard cover, 232 pages

Publisher InTech

Published online 16, December, 2011

Published in print edition December, 2011

The objective of this multi-disciplinary book is to provide a collection of expert writing on different aspects of pre- and post- tsunami developments and management techniques. It is intended to be distributed within the scientific community and among the decision makers for tsunami risk reduction. The presented chapters have been thoroughly reviewed and accepted for publication. It presents advanced methods for tsunami measurement using Ocean-bottom pressure sensor, kinematic GPS buoy, satellite altimetry, Paleotsunami, lonospheric sounding, early warning system, and scenario based numerical modeling. It continues to present case studies from the Northern Caribbean, Makran region and Tamil Nadu coast in India. Furthermore, classifying tsunamis into local, regional and global, their possible impact on the region and its immediate vicinity is highlighted. It also includes the effects of tsunami hazard on the coastal environment and infrastructure (structures, lifelines, water resources, bridges, dykes, etc.); and finally the need for emergency medical response preparedness and the prevention of psychological consequences of the affected survivors has been discussed.

\title{
How to reference
}

In order to correctly reference this scholarly work, feel free to copy and paste the following:

Mario Octavio Cotilla Rodríguez and Diego Córdoba Barba (2011). Comments About Tsunami Occurrences in the Northern Caribbean, Tsunami - A Growing Disaster, Prof. Mohammad Mokhtari (Ed.), ISBN: 978-953-307431-3, InTech, Available from: http://www.intechopen.com/books/tsunami-a-growing-disaster/commentsabout-tsunami-occurrences-in-the-northern-caribbean

\section{INTECH}

open science | open minds

\section{InTech Europe}

University Campus STeP Ri

Slavka Krautzeka 83/A

51000 Rijeka, Croatia

Phone: +385 (51) 770447

Fax: +385 (51) 686166

www.intechopen.com

\section{InTech China}

Unit 405, Office Block, Hotel Equatorial Shanghai

No.65, Yan An Road (West), Shanghai, 200040, China 中国上海市延安西路65号上海国际贵都大饭店办公楼 405 单元

Phone: +86-21-62489820

Fax: +86-21-62489821 
(C) 2011 The Author(s). Licensee IntechOpen. This is an open access article distributed under the terms of the Creative Commons Attribution 3.0 License, which permits unrestricted use, distribution, and reproduction in any medium, provided the original work is properly cited. 